\title{
əon the Generation of Weddell Sea Polynyas in a High-Resolution Earth System Model $\mathscr{O}$
}

\author{
Prajvala Kurtakoti, ${ }^{\mathrm{a}, \mathrm{b}, \mathrm{c}}$ Milena Veneziani, ${ }^{\mathrm{b}}$ Achim Stössel,${ }^{\mathrm{c}}$ Wilbert Weijer,${ }^{\mathrm{d}}$ And Mathew Maltrud ${ }^{\mathrm{b}}$

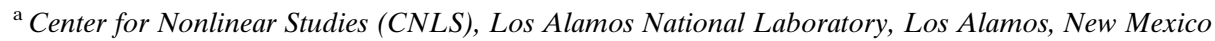 \\ ${ }^{\mathrm{b}}$ Fluid Dynamics and Solid Mechanics (T-3), Los Alamos National Laboratory, Los Alamos, New Mexico \\ ${ }^{\mathrm{c}}$ Department of Oceanography, Texas A\&M University, College Station, Texas \\ ${ }^{\mathrm{d}}$ Computational Physics and Methods (CCS-2), Los Alamos National Laboratory, Los Alamos, New Mexico
}

(Manuscript received 3 April 2020, in final form 21 December 2020)

\begin{abstract}
Larger Weddell Sea polynyas (WSPs), differentiated in this study from the smaller Maud Rise Polynyas (MRPs) that form to the east of the prime meridian in the proximity of the Maud Rise seamount, have last been observed in the 1970s. We investigate WSPs that grow realistically out of MRPs in a high-resolution preindustrial simulation with the Energy Exascale Earth System Model, version 0.1. The formation of MRPs requires high resolution to simulate the detailed flow around Maud Rise, whereas the realistic formation of WSPs requires a model to produce MRPs. Furthermore, WSPs tend to follow periods of a prolonged buildup of a heat reservoir at depth and weakly negative wind stress curl in association with the core of the Southern Hemisphere westerlies at an anomalously northern position. While this scenario also leads to drier conditions over the central Weddell Sea, which some literature claims to be a necessary condition for the formation of WSPs, our model results indicate that open-ocean polynyas do not occur during periods of weakly negative wind stress curl despite drier atmospheric conditions. Our study supports the hypothesis noted in earlier studies that a shift from a weakly negative to a strongly negative wind stress curl over the Weddell Sea is a prerequisite for WSPs to form, together with a large heat reservoir at depth. However, the ultimate trigger is a pronounced MRP, whose associated convection creates high surface salinity anomalies that propagate westward with the flow of the Weddell Gyre. If large enough, these anomalies trigger the formation of a WSP and a pulse of newly formed Antarctic Bottom Water.
\end{abstract}

KEYWORDS: Southern Ocean; Atmosphere-ocean interaction; Deep convection; Ocean circulation; Ocean dynamics; Climate models

\section{Introduction}

The Weddell Gyre is a crucial oceanic component of the global climate pathway because of its role in the formation of dense water masses and long-term sequestration of atmospheric heat and carbon (Marinov et al. 2006; Fahrbach et al. 1994; Foldvik et al. 1985). This region is the most important source of Antarctic Bottom Water (AABW; Orsi et al. 1993), produced through both coastal polynyas (Morales Maqueda et al. 2004) and open-ocean polynyas (Martinson et al. 1981). The long-term sequestration of atmospheric heat and carbon (e.g., Hoppema 2004) in the Weddell Sea occurs through deep convection (de Lavergne et al. 2014) and subsequent dense water formation. Deep convection occurs regularly along the coastal areas of Antarctica (coastal polynyas) and, until 1980, presumably intermittently in the central Weddell Sea (openocean polynyas) in the austral winter (Morales Maqueda et al. 2004; Zhang et al. 2015).

๑ Denotes content that is immediately available upon publication as open access.

Supplemental information related to this paper is available at the Journals Online website: https://doi.org/10.1175/JCLI-D-200229.s1.

Corresponding author: Prajvala Kurtakoti, prajvala@lanl.gov
Open-ocean polynyas in the Weddell Sea appear as openings in the winter sea ice cover that expose the ocean to the cold atmosphere, leading to strong atmosphere-ice-ocean interaction, thereby enhancing deep convection and dense water formation. Physical processes in the Weddell Sea thus have a significant impact on the characteristics and formation of AABW. Weddell Sea polynyas (WSPs) are winter-long openocean polynyas in the Weddell Sea, such as the ones observed during the austral winters of 1974-76 (Gordon 1982). WSPs predominantly occur west of the prime meridian in the open ocean, where the average ocean depths are greater than $4500 \mathrm{~m}$. This phenomenon was observed remotely via satellite in three consecutive winters, and, since the timing coincided with the first satellite retrievals of its kind, it was assumed to be a typical event at first. However, as it turned out, a full-scale WSP has not emerged ever since, whereas smaller short-lived polynyas in the vicinity of the Maud Rise Seamount (hereinafter referred to as MRPs) have occurred sporadically and most recently during the winters of 2016 and 2017. The term MRP is used to describe small open-ocean polynyas that form over and around the Maud Rise seamount (the seamount is $200 \mathrm{~km}$ in diameter and extends from the ocean floor up to $1700 \mathrm{~m}$ below the ocean surface) located east of the prime meridian. MRPs are confined to bathymetric features, whereas WSPs are not.

The sudden cessation of WSPs has been attributed to an increase in upper-ocean stratification due to anthropogenic climate change (e.g., Gordon 2014; de Lavergne et al. 2014). One idea is that the present-day poleward shift in Southern 
Hemisphere westerlies due to anthropogenic $\mathrm{CO}_{2}$ emissions and ozone depletion (Oke and England 2004; Russell et al. 2006; Fyfe et al. 2007) results in a positive trend of the southern annular mode (SAM) index, leading to an increase in precipitation over the Weddell Sea, freshening of the surface ocean, and flattening of the isopycnals in the upper ocean (Gordon 2014), thus increasing stratification. Furthermore, the associated increase in Ekman divergence increases the interaction of the subsurface heat reservoir in the Weddell Gyre with the ice shelves, thereby increasing glacial melt, which contributes to surface freshening (Rignot et al. 2013). The total sum of the anthropogenic effects has resulted in a warming and freshening of the Southern Ocean north of the Antarctic Circumpolar Current (ACC) (Swart et al. 2018). South of the ACC, the anthropogenic effects have mostly led to a surface cooling and freshening (Armour et al. 2016; Swart et al. 2018), and the absence of WSPs since the late 1970s appears to be one of its consequences (de Lavergne et al. 2014). On the other hand, intensifying winds over the high-latitude Southern Ocean during a positive SAM phase also lead to a spinup of the Weddell Gyre (Cheon et al. 2014), which then causes the doming of isopycnals, which is traditionally considered to be one of the mechanisms leading up to a WSP (Hirabara et al. 2012; Cheon et al. 2015).

Formation processes of WSPs have been studied extensively since the polynyas were first detected in satellite passivemicrowave images (Carsey 1980; Martinson et al. 1981; Gordon 1982; Zwally et al. 1983; Parkinson 1983). An early study by Martinson et al. (1981) described an idealized convective model for the WSP in which the sequence of a preconditioned area in the ocean, combined with some factor that can act as a trigger, can lead to static instability, which can further lead to deep convection. Once convection was triggered in winter, a subsurface heat source-in this case, the warm and salty Weddell Deep Water (WDW)-helped to maintain the WSP by melting sea ice or instead prohibiting its formation. The 1970s monthly satellite-derived winter sea ice concentration in the WSP region indeed shows that sea ice formed around an area of warm surface water (Martinson et al. 1981; Zwally et al. 1983). Subsequent literature on the preconditioning and formation mechanisms of open-ocean polynyas includes the investigation of both large-scale processes, such as the intensification of the Weddell Gyre described above, and small-scale processes, such as the bathymetric effects and formation of Taylor caps around the Maud Rise seamount (Alverson and Owens 1996; Martinson et al. 1981; Dufour et al. 2017; de Steur et al. 2007; Kurtakoti et al. 2018). While low-resolution (LR) forced ice-ocean general circulation models (GCMs) or coupled Earth system models (ESMs) with LR ocean components would not be able to resolve smallscale processes, some LR ocean GCMs and ESMs can simulate WSPs, either permanently (de Lavergne et al. 2014; Stössel et al. 2015) or intermittently (Hirabara et al. 2012; Martin et al. 2013; Cheon et al. 2014).

Using a high-resolution fully coupled Energy Exascale Earth System Model (E3SMv0-HR) simulation, Kurtakoti et al. (2018) found that an important preconditioning for MRP formation is the Taylor cap dynamics occurring around the
Maud Rise seamount and Astrid Ridge to the east of Maud Rise (the Maud Rise-Astrid Ridge complex, referred to herein as the MR-AR complex). Furthermore, the model results show that advection of high surface salinity waters over the MR-AR complex is the main trigger for deep convection in that region. Kurtakoti et al. (2018) also indicated that the formation of MRPs in ESMs requires a detailed representation of the bathymetry for tall enough Taylor columns to form and affect the mixed layer and circulation around Maud Rise (Meredith et al. 2015). The associated dynamics lead to the representation of several small-scale features in the simulation, namely 1) the doming of isopycnals over Maud Rise; 2) a ring or crescent of anomalously warm and salty WDW around Maud Rise, which causes a halo of lower sea ice concentration; 3) a positive icedrift vorticity along the northwestern flank of Maud Rise; and 4) an anticyclonic outer circulation and a cyclonic inner circulation around Maud Rise, all of which are supported by observational and theoretical studies of MRPs (Gordon and Huber 1990; Bersch et al. 1992; Alverson and Owens 1996; Muench et al. 2001; Holland 2001; de Steur et al. 2007). More recent studies of the MRPs observed in the winters of 2016 and 2017 converge on the finding that these MRPs have ultimately been triggered by the passage of strong winter storms over the region (Francis et al. 2019; Jena et al. 2019; Campbell et al. 2019; Wilson et al. 2019).

It is only recently that we have been in a position to simulate the sequence of events that lead up to WSPs in HR fully coupled ESMs. This is especially relevant if we wish to ultimately investigate the impact of open-ocean polynyas on AABW formation, meridional overturning circulation (Stössel and Kim 2001; Swingedouw et al. 2009; Hirabara et al. 2012; Martin et al. 2013; Patara and Böning 2014; Zanowski et al. 2015; Zanowski and Hallberg 2017; Sohail et al. 2020), and the climate system (Kaufman et al. 2020).

In this study, we analyze the preconditioning, triggering, and the onset of WSPs that begin over the MR-AR bathymetric complex and expand westward into the Weddell Sea as simulated with E3SMv0-HR under preindustrial atmospheric $\mathrm{CO}_{2}$ forcing. We, therefore, set about addressing the following questions: What causes convection associated with MRPs to spread westward into the western Weddell Sea and lead to WSPs? If MRPs are a prerequisite for the occurrence of WSPs, why do not all MRPs lead to WSPs? The second question partly addresses a possible reason for the 2016/17 MRPs failing to grow into full WSPs in subsequent winter seasons.

The paper is organized as follows. The following section describes the model simulation with a focus on the Weddell Gyre and WSPs. Our main results are presented in section 3, and a discussion and conclusions are included in section 4 .

\section{Model description, evaluation, and analysis strategy}

The E3SMv0-HR simulation analyzed in this study is the same simulation utilized in Kurtakoti et al. (2018) and Kaufman et al. (2020). The E3SMv0 model is based on the Community Earth System Model (CESM; Hurrell et al. 2013); its atmosphere component is the Community Atmosphere Model, version 5, with the spectral element dynamical core (CAM5-SE; Dennis et al. 2011); the land component is the 
TABLE 1. Terminologies used for the different types of open-ocean polynyas in the Weddell Sea.

\begin{tabular}{lll}
\hline \multicolumn{1}{c}{ Description } & $\begin{array}{c}\text { Acronym used in } \\
\text { the paper }\end{array}$ & Years \\
\hline $\begin{array}{l}\text { Maud Rise Polynya: open-ocean polynya } \\
\text { over the Maud Rise-Astrid Ridge } \\
\text { complex }\left(0^{\circ}-15^{\circ} \text { E } \sim 65^{\circ}\right)\end{array}$ & MRP & $\begin{array}{c}\text { Years 24-25, 31-39, 47-49, 64-66, 69-74, } \\
\text { and 101-102 }\end{array}$ \\
$\begin{array}{l}\text { Year of transition from no polynya to } \\
\text { initiation of the first MRP }\end{array}$ & MRP-I years & Years 24, 31, 47, 64, 69, and 101 \\
$\begin{array}{l}\text { The last no-polynya year preceding an } \\
\text { MRP-I year }\end{array}$ & MRP-P years & Years 23, 30, 46, 63, 68, and 100 \\
$\begin{array}{l}\text { Weddell Sea polynya: Large open-ocean } \\
\text { polynya in central Weddell Sea pre- } \\
\text { dominantly west of Maud Rise }\end{array}$ & WSP & Years 26-27,50-62,75-79, and 103-123 \\
$\begin{array}{l}\text { Years of MRP that evolve into WSP } \\
\begin{array}{l}\text { Years of MRPs that do not develop } \\
\text { into WSPs }\end{array}\end{array}$ & $\begin{array}{l}\text { MRP+WSP years } \\
\text { Years with no open-ocean polynyas }\end{array}$ & MRP years \\
\hline
\end{tabular}

Community Land Model, version 4.5 (CLM4.5; Lawrence et al. 2011); the ocean component consists of the Parallel Ocean Program, version 2 (POP2), model (Smith et al. 2010); and finally, the sea ice component is the Community Ice Code, version 4 (CICE4), model (Hunke and Lipscomb 2008). In E3SMv0-HR, the atmosphere and land model components have a nominal $0.25^{\circ}$ horizontal resolution, while the ocean and sea ice models feature a tripolar grid with a nominal $0.1^{\circ}$ horizontal resolution and 42 vertical levels (vertical resolution varies between $10 \mathrm{~m}$ at the surface and $250 \mathrm{~m}$ near the bottom). Parameterizations in the ocean component of E3SMv0-HR include the $K$-profile boundary layer scheme of Large et al. (1994) to represent unresolved vertical mixing processes and a biharmonic scheme for subgrid-scale horizontal mixing of momentum and tracers. The simulation was run for 131 years under preindustrial conditions, and it was initialized from year 34 of a previous E3SMv0 simulation, whose POP/CICE components were in turn initialized from a short forced simulation (which started from rest/climatology) and whose CAM/CLM components were initialized from a standard Atmospheric Model Intercomparison Project run. For a general description of the E3SMv0-HR overall performance we refer the reader to Kurtakoti et al. (2018). This section evaluates the Weddell Sea representation in the simulation against observations and compares the simulated WSPs with those observed in 1974-76.

The reasoning for the distinction between MRPs and WSPs follows from the fact that the formation mechanism of MRPs is fundamentally different from that of WSPs. As described in Kurtakoti et al. (2018), the simulated MRPs are triggered by advection of high surface salinity anomalies over Maud Rise and Astrid Ridge (the MR-AR bathymetric complex; see section 1), where deep convection and polynya formation is prone to occur due to topographic preconditioning (via Taylor column dynamics). Under certain conditions, MRPs expand westward into the central Weddell Sea, at which point we name them WSPs. In the time series where we distinguish between no-polynya, MRP, and WSP years over the course of the E3SMv0-HR simulation, an MRP year is defined to emerge when there is a closed contour of austral winter (July-October) averaged $0 \%$ sea ice concentration geographically located east of the prime meridian and over and around the MR-AR complex. Similarly, a WSP year is defined to emerge when the ice-free area enclosed by sea ice extends west beyond the prime meridian. In some years, the WSPs grow into larger "embayments" (EMBs), meaning that open water is not totally enclosed by sea ice. The type of simulated open-ocean polynya and the simulation year it occurs in are listed in Table 1 (see the online supplemental material for an animation of monthly sea ice concentration of E3SMv0-HR).

Spatial maps of monthly climatology of simulated sea ice thickness overlapped with the $15 \%$ concentration contour are shown in Fig. 1 (climatologies are computed over the no-polynya years; see Table 1), together with satellite-derived ice extent (green contour). Sea ice thickness is generally lower over the MR-AR complex than in the central Weddell Sea. Figure 1 shows evidence of coastal polynyas, in particular along the Ronne ice shelf in the western Weddell Sea, indicated by lower ice thickness. Overall, the seasonal variation of the ice extent (green vs white line) is reasonably well simulated, except perhaps in autumn, when the satellite-derived product suggests a faster extension of the ice cover. The ice thickness being in winter mostly around $0.5 \mathrm{~m}$ and being distributed such that the thickest ice resides in the western Weddell Sea and survives the summer melt (multiyear ice) appears also to be realistic as far as ice thickness can be verified (Worby et al. 2008; Kurtz and Markus 2012; Williams et al. 2015).

The Weddell Gyre circulation is described in Fig. 2 by means of the barotropic volume transport streamfunction averaged over simulation years 50-127. The modeled circulation compares well to observations, clearly revealing the characteristic double-cell structure of the gyre (Timmermann 2002; Fahrbach et al. 2011; Ryan et al. 2016; Armitage et al. 2018), and the intricate pattern in the eastern cell. In particular, E3SMv0-HR captures the observed eddy noisiness of the eastern cell, which is mainly determined by the wind field, ocean stratification, and subtle bathymetric features (Orsi et al. 1993; Schröder and Fahrbach 1999; Ryan et al. 2016). The circulation pattern of the eastern Weddell Gyre is particularly important for this study 

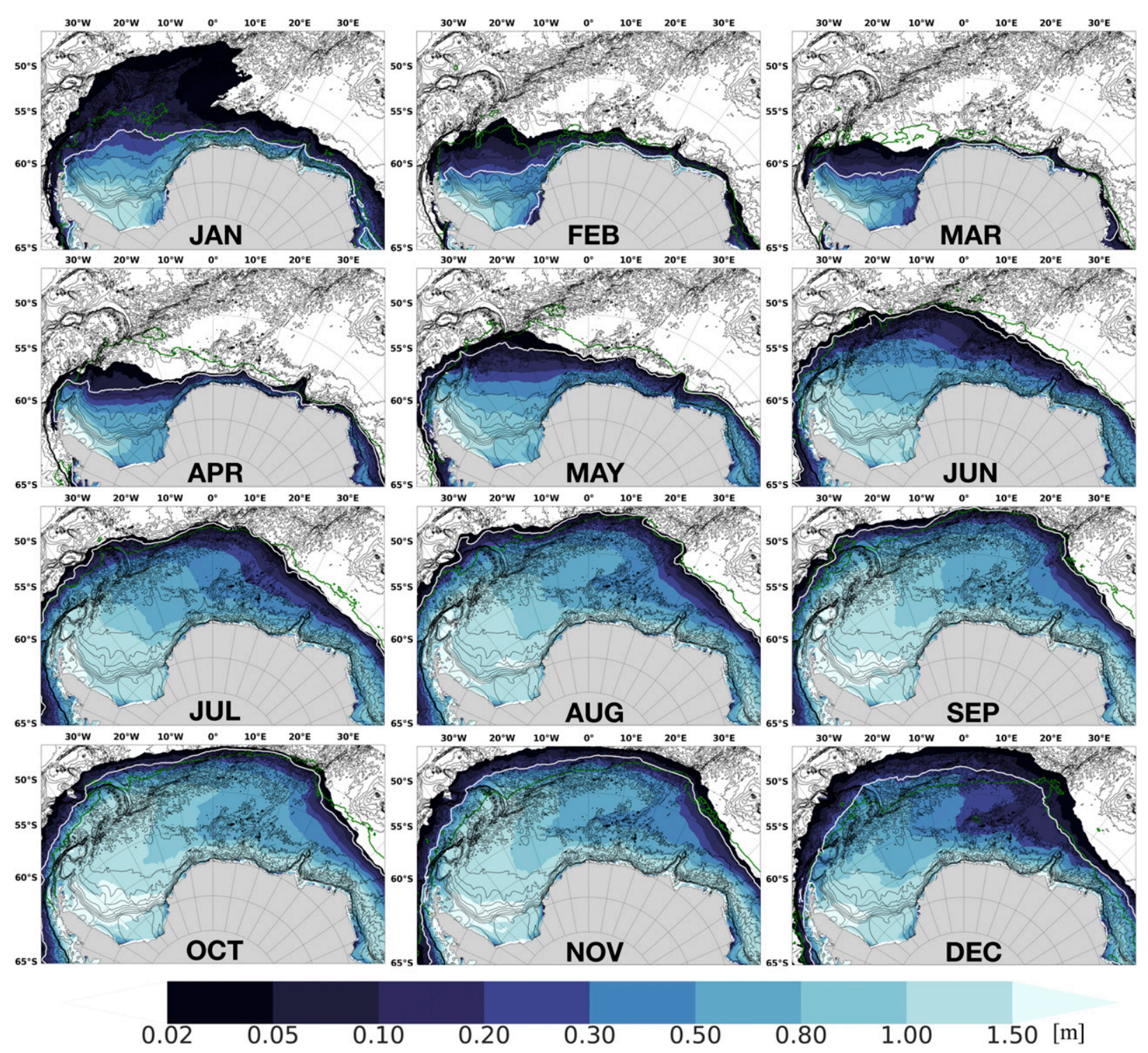

FIG. 1. Simulated monthly climatology of sea ice thickness, where the climatologies are calculated over no-polynya years (refer to Table 1). The white contour represents the model $15 \%$ sea ice concentration, whereas the green contour is the observed $15 \%$ ice extent from satellite passive microwave (climatology over 1978-2018). Black contours represent the 1000-, 2000-, and 3000-m bathymetry lines.

since it affects the stratification of the upper ocean upstream of the MR-AR complex.

Meridional cross sections of temperature and salinity along $0^{\circ}$ and $35^{\circ} \mathrm{E}$ for the September month climatology (with climatologies computed over years 50-127) are used to visualize the hydrographic properties and stratification within the simulated Weddell Gyre (Figs. 3 and 4). These cross sections compare exceptionally well with directly observed hydrographic data (e.g., Schröder and Fahrbach 1999, their Figs. 4 and 5; Ryan et al. 2016, their Figs. 3 and 6). It is remarkable that the Weddell Sea is well represented in E3SMv0-HR because maintaining a realistic stratification in the high-latitude Southern Ocean in fully coupled climate models can be very challenging (Stössel et al. 2015; Kjellsson et al. 2015).
The meridional cross section along the Greenwich meridian (Fig. 3) shows the deep water in the core of the gyre between $57^{\circ}$ and $63^{\circ} \mathrm{S}$ doming upward, very similar to the observations, both in terms of structure and $T$ and $S$ values. This water mass is the Weddell Sea Deep Water (WSDW) that fills the bottom of the basin up to $\sim 69^{\circ} \mathrm{S}$ in the south and $\sim 55^{\circ} \mathrm{S}$ in the north. At intermediate depths of $200-2000 \mathrm{~m}$, a warm and salty water mass apparently circulates the dome of colder and fresher water. This water mass is the Weddell Deep Water (WDW) at the southern rim of the gyre, and the Circumpolar Deep Water (CDW) transitioning into WDW at the northern rim of the gyre (Orsi et al. 1993; Fahrbach et al. 2011).

The meridional cross section along $35^{\circ} \mathrm{E}$ (Fig. 4) reflects the very eastern edge of the Weddell Gyre. The observations for 


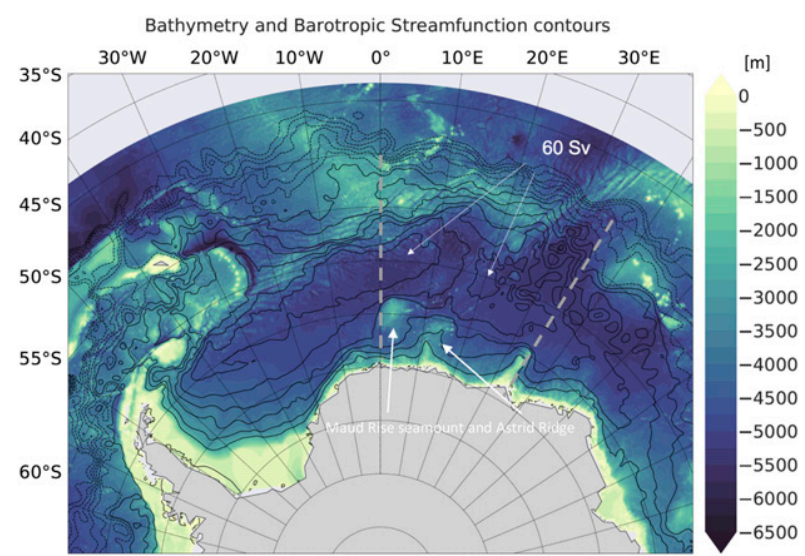

FIG. 2. Bathymetry of Weddell Sea and surrounding areas (shading; $\mathrm{m}$ ) in E3SMv0-HR, with contours of the barotropic volume transport stream function climatology showing the Weddell Gyre circulation. The contours (increments every $10 \mathrm{~Sv}$ ) indicate the zonal and meridional extent of the cyclonic double-cell Weddell Gyre. The gray dashed lines indicate the location of the meridional cross sections shown in Figs. 3 and 4, below. The locations of the Maud Rise seamount and Astrid Ridge are also indicated.

this region end at $65^{\circ} \mathrm{S}$, so we can only compare the structure north of $65^{\circ} \mathrm{S}$. As expected, and consistent with the observations, there is no strong doming of properties in the central part of the section. The isotherms primarily dip down the

a) Meridional Cross Section of Temperature along $0^{\circ} \mathrm{E}$ : September Climatology

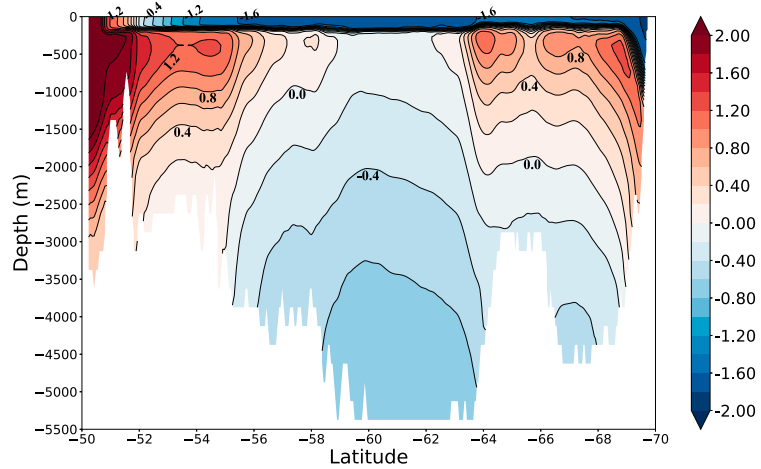

b) Meridional Cross Section of Salinity along $0^{\circ} \mathrm{E}$ : September Climatology

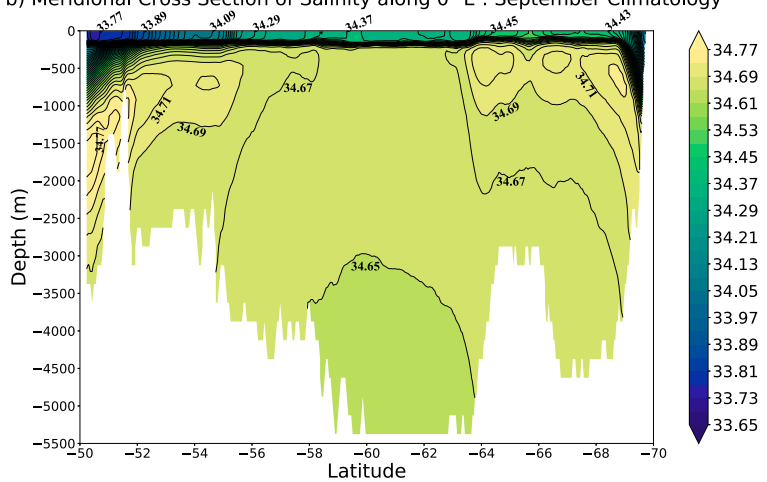

FIG. 3. Simulated September climatology calculated over nopolynya years (refer to Table 1) of (a) temperature and (b) salinity in the central Weddell Sea along $0^{\circ}$. a) Meridional Cross Section of Temperature along $35^{\circ} \mathrm{E}$ : September Climatology

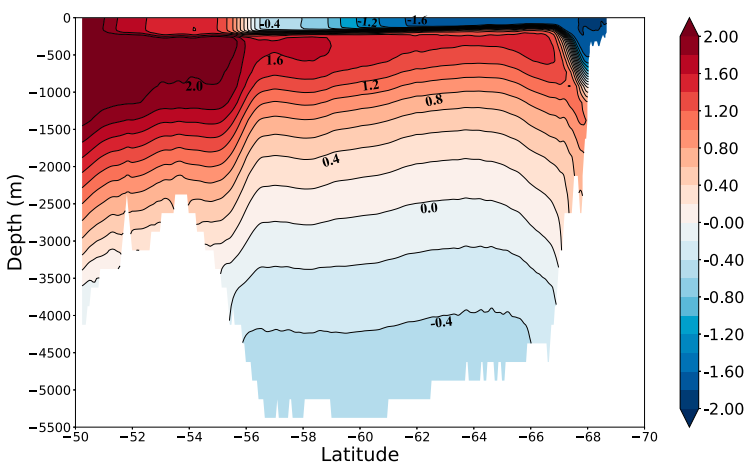

b) Meridional Cross Section of Salinity along $35^{\circ} \mathrm{E}$ : September Climatology

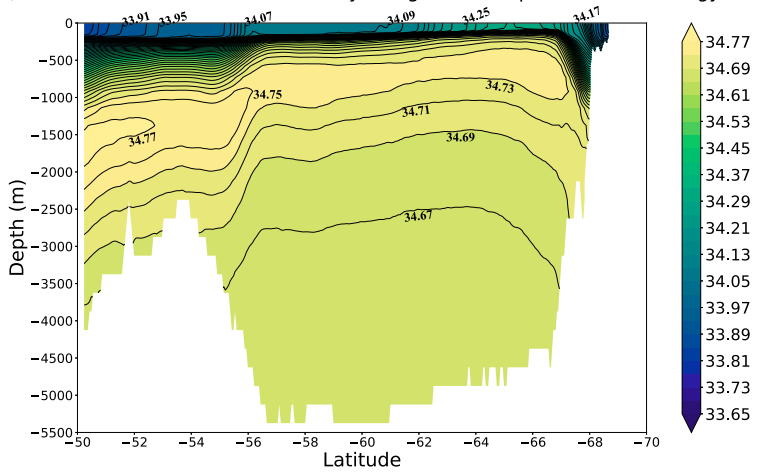

FIG. 4. As in Fig.3, but along $35^{\circ} \mathrm{E}$.

continental slope with a weak dome between $64^{\circ}$ and $66^{\circ} \mathrm{S}$. The main difference between Figs. 3 and 4 is in the temperature and salinity values between 200 and $2000 \mathrm{~m}$, in that this subsurface water mass is significantly warmer and saltier along $35^{\circ} \mathrm{E}$ than along the prime meridian.

Figures 1 and 2 in the online supplemental material show comparisons between simulated and Southern Ocean State Estimate (SOSE) salinity and temperature at the surface and 500-m depth, for the climatological months of February (online supplemental Fig. 1) and September (online supplemental Fig. 2). The SOSE reanalysis data are generated from an ocean model that assimilates observations during 2005-06 (Mazloff et al. 2010). SOSE version-2 data have a resolution of about $1 / 6^{\circ}$ and consist of 42 depth levels. While similarities can readily be identified, one should note that the E3SMv0-HR simulation has been run under preindustrial conditions, while SOSE represents in essence present-day conditions. Both in February and September, the model surface salinities are similar to those in SOSE, but the surface temperatures are not. The surface temperature of the Weddell Sea in the E3SMv0HR simulation is warmer than that of SOSE, likely because of the presence of large open-ocean polynyas and a more dynamic sea ice cover in the model. The subsurface ocean at 500-m depth in the eastern Weddell Sea is warmer and saltier in E3SMv0-HR than in SOSE, which indicates a more vigorous infusion of CDW into the Weddell Gyre in the former, consistent with a $30 \%$ weaker gyre transport in SOSE (about $40 \mathrm{~Sv} ; 1 \mathrm{~Sv} \equiv 10^{6} \mathrm{~m}^{3} \mathrm{~s}^{-1}$ ) relative to E3SMv0-HR (about $60 \mathrm{~Sv}$; 

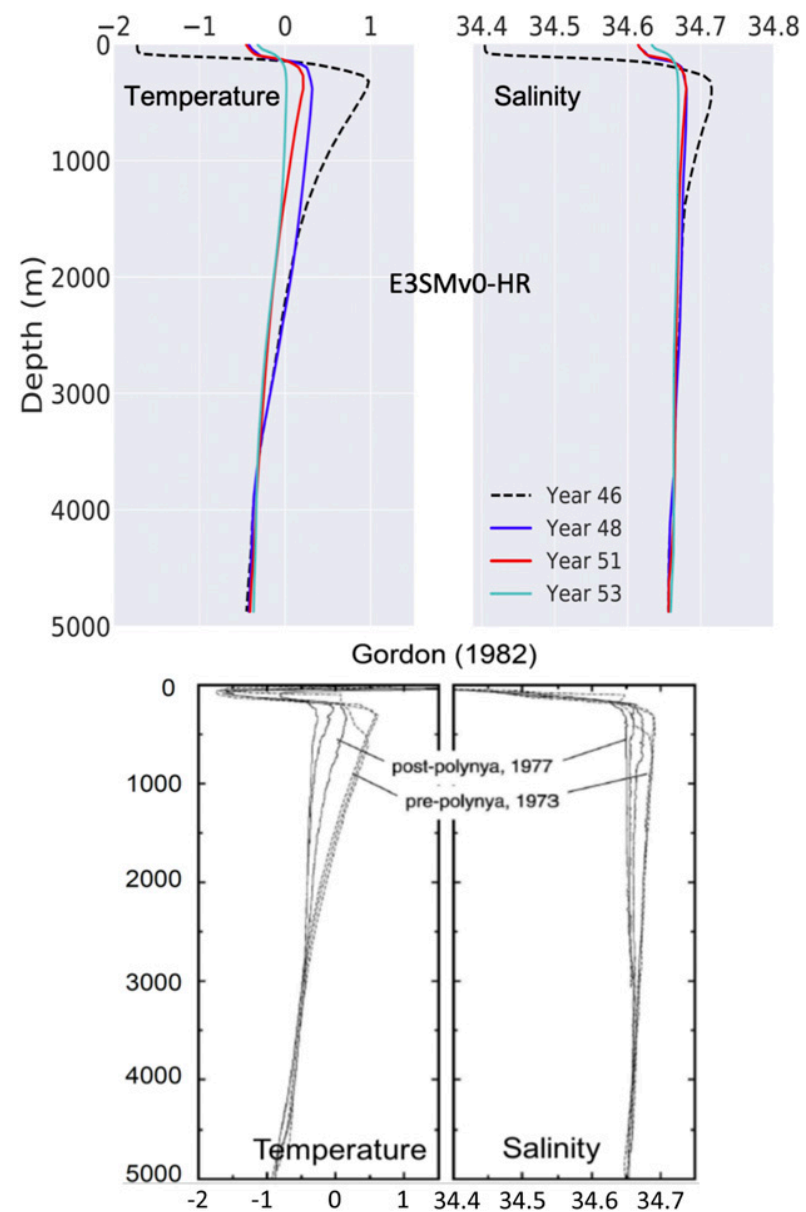

FIG. 5. (top) Profiles of annual mean (left) temperature and (right) salinity of model simulation: year 46 with no polynya and years in the 50s with strong WSPs. Also shown are (bottom) profiles of observed [from Gordon (1982)] (left) potential temperature and (right) salinity. The temperature and salinity fields are averaged over the region that matches the areas of the different stations from where the observations come [hydrographic stations: Glacier in 1973 and Islas Orcadas in 1977; refer to Gordon (1982)].

Fig. 2). On the other hand, the subsurface ocean in the central Weddell Sea is much colder in E3SMv0-HR than in SOSE, consistently with a more pronounced doming of colder and fresher WSDW in a stronger gyre (see Fig. 3).

To evaluate the realism of the simulated WSPs, we next investigate the regional ocean properties before and after the onset of WSPs and compare them with those observed before and after the WSPs of the mid-1970s (Fig. 5). The model results were averaged over the hydrographic stations where the observations were made in Gordon (1982). Years 46 (MRP-P year) and 48 (MRP year) in Fig. 5 represent conditions prior to the simulated WSP and year 51 is the first WSP year followed by several consecutive WSP years. The deep convective events associated with the WSP lead to a reduction of temperature and salinity below $200 \mathrm{~m}$ down to 3000-m depth (Fig. 5, upper panels), suggesting deep water ventilation in the Weddell Sea.
The differences of the simulated temperature and salinity profiles between pre- and post-WSP conditions are strikingly similar to those of the observations made in 1973 (pre-WSP) and 1977 (post-WSP) (Fig. 5, lower panels) in magnitude, shape, and depth. The drastic loss of heat in the core of WDW and down to $\sim 3000 \mathrm{~m}$ affects the volume and characteristics of the deep and bottom water masses in this region. Therefore, WSPs can drastically increase the formation of bottom waters in the Weddell Sea and modify their properties through the contribution of surface waters, and have been estimated to be comparable to the impact of coastal polynyas on AABW formation (Gordon 1982). Thus, it is equally important to understand the impact of a lack of WSPs on the properties and volume of water masses in the deep Weddell Sea in the last 40 years.

To show how the different open-ocean polynyas were classified into MRP and WSP in E3SMv0-HR and verify them against observations (Chapman and Walsh 1996; Maslanik and Stroeve 1999), we compare spatial winter sea ice concentration in simulation and available observations (Fig. 6). The 2017 MRP is comparable to the MRP in year 33 in E3SMv0-HR (Figs. 6a,b) where the monthly maximum mixed layer depth is $\sim 2000 \mathrm{~m}$. The $1974 \mathrm{WSP}$ is comparable to the WSP in year 51 in E3SMv0-HR (Figs. 6c,d) where the maximum monthly mixed layer depths are $>3000 \mathrm{~m}$ in parts of the Weddell Sea. The main reason to differentiate the two types of open-ocean polynyas is because of differences in their formation mechanism. The realistic formation mechanism of MRP in E3SMv0HR requires the representation of bathymetry and the flow around it to simulate the small-scale processes that precondition the region for convection (Kurtakoti et al. 2018; Alverson and Owens 1996; de Steur et al. 2007; Comiso and Gordon 1987). The realistic formation of WSP depends on both MRP formation and preconditioning of the Weddell Sea through large-scale circulation shown in the following section.

In the next section, we focus on the formation of WSPs and their transformation from MRPs. We study four independent WSP events that begin as MRPs over the MR-AR complex and spread westward into the Weddell Sea over consecutive years, thereby developing into full-scale WSPs (see Table 1). We refer to the four cases in which MRPs transition into WSPs as "MRP+WSP" years. The years with MRP events that do not develop into WSPs are instead simply referred to as "MRP" years (Table 1).

\section{Results}

We investigate the development of WSPs in the E3SMv0HR simulation in the following steps. First, we consider the role played by the position and relative strength of the Southern Hemisphere westerlies in affecting the regional wind stress curl (section 3a) and precipitation (section 3b), as well as their relationship with the SAM index. In section $3 \mathrm{c}$ we discuss the large-scale preconditioning of the Weddell Sea for MRP and subsequent WSP development in terms of its stratification. Subsequently, we focus on how WSPs grow out of MRPs (section 3d). Since not all MRPs lead to WSPs, this section reveals new insights into the specific necessary conditions for 
a) Year 2017 Maud Rise Polynya

b) E3SMv0-HR (Year 33) Maud Rise Polynya
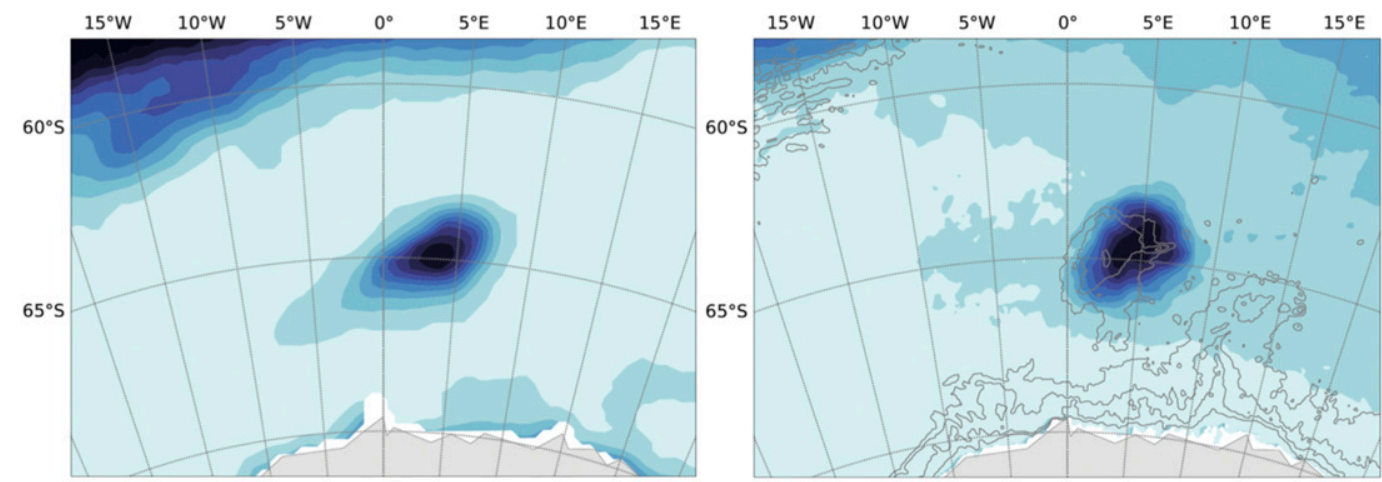

c) Year 1974 Weddell Sea Polynya

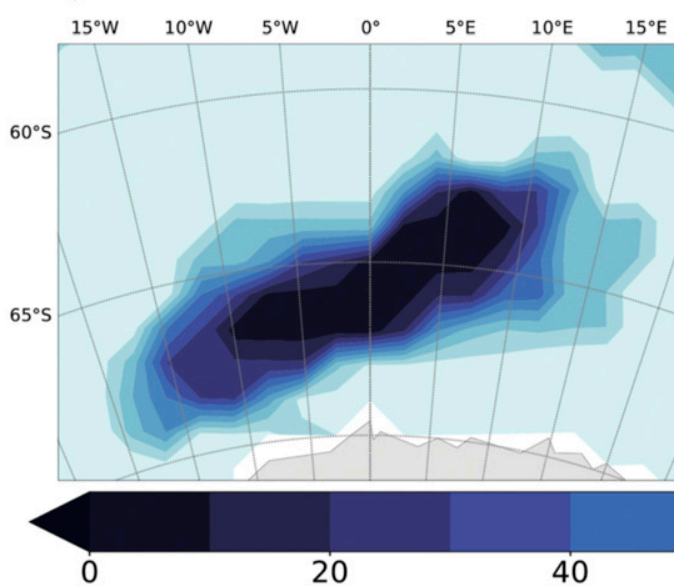

d) E3SMv0-HR (Year 51) Weddell Sea Polynya

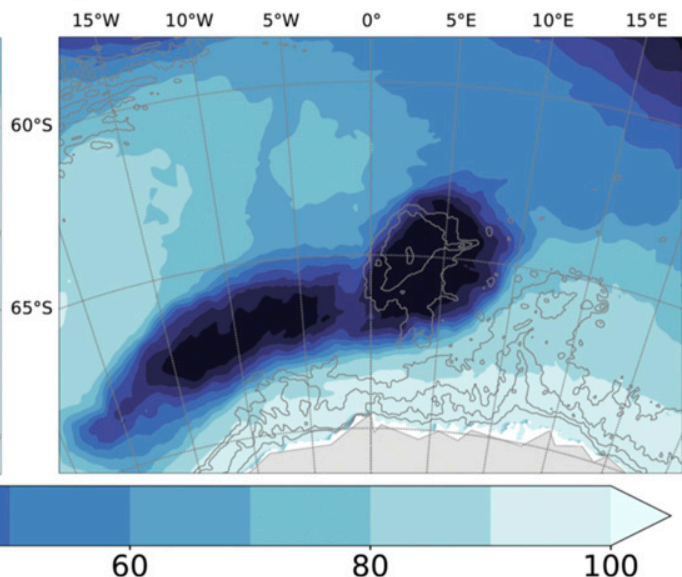

FIG. 6. Austral winter (July-October) sea ice concentration of the (a) observed 2017 MRP (Maslanik and Stroeve 1999) and (b) simulated MRP (year 33) in E3SMv0-HR in the eastern Weddell Sea (deep convection within the MRP occurs predominantly over bathymetric features). Also shown is winter sea ice concentration of the (c) observed 1974 WSP (Chapman and Walsh 1996), and (d) simulated WSP (year 51) E3SMv0-HR (deep convection within the WSP occurs over the deep ocean in the central Weddell Sea and is not restricted to just over the bathymetric features in the eastern Weddell Sea).

this to happen. Last, we will scrutinize the local initiation of convection by analyzing daily output fields (section 3e).

\section{a. Role of changes in the Southern Hemisphere westerlies}

As found in previous studies (see section 1), there is a direct relationship between anomalously negative wind stress curl and a weakening of the pycnocline strength of the upper ocean in the Weddell Sea (Fig. 7a) averaged over the region $55^{\circ} \mathrm{W}-$ $40^{\circ} \mathrm{E}, 50^{\circ}-70^{\circ} \mathrm{S}$. Low values of both the pycnocline and halocline strength indicate doming of isopycnals in the Weddell Sea possibly as a result of a spinup of the Weddell Gyre following the negative wind stress curl anomalies. The time series of the pycnocline strength being almost identical to that of the halocline strength suggests that the variability of the former is almost solely due to salinity. During the WSP events (see blue/ gray shaded regions in Fig. 7a) the wind stress curl anomaly is predominantly negative. The opposite is also true; that is, during the no-polynya years (white shaded regions) the wind stress curl anomaly is mostly positive. During MRP events (green shading in Fig. 7a), the wind stress curl anomaly is either positive or negative, but predominantly negative when followed by a WSP. As will be seen in section $3 \mathrm{~d}$, this finding is relevant for explaining large MRPs. The wind stress curl is calculated over the entire Weddell Sea region and does not necessarily reflect the conditions over Maud Rise, such as the local stratification, which may depend on several other factors such as the strength of the impinging flow, the local wind stress curl field, and the presence of Taylor caps (Kurtakoti et al. 2018). The main message here is that the wind stress curl anomalies go from being strongly positive to strongly negative while overlapping the gradual transition from no polynyas to the onset of large WSPs via MRPs (Fig. 7a).

\section{$b$. Role of precipitation in conjunction with southward shift of the westerlies}

The simulated full precipitation and wind stress curl anomaly over the Weddell Sea are inversely related (Fig. 7b). Higher precipitation rates are a result of southward shifted westerlies. The poleward moving westerlies coincide with negative wind stress curl anomalies (Fig. 8), and open-ocean polynyas in the 

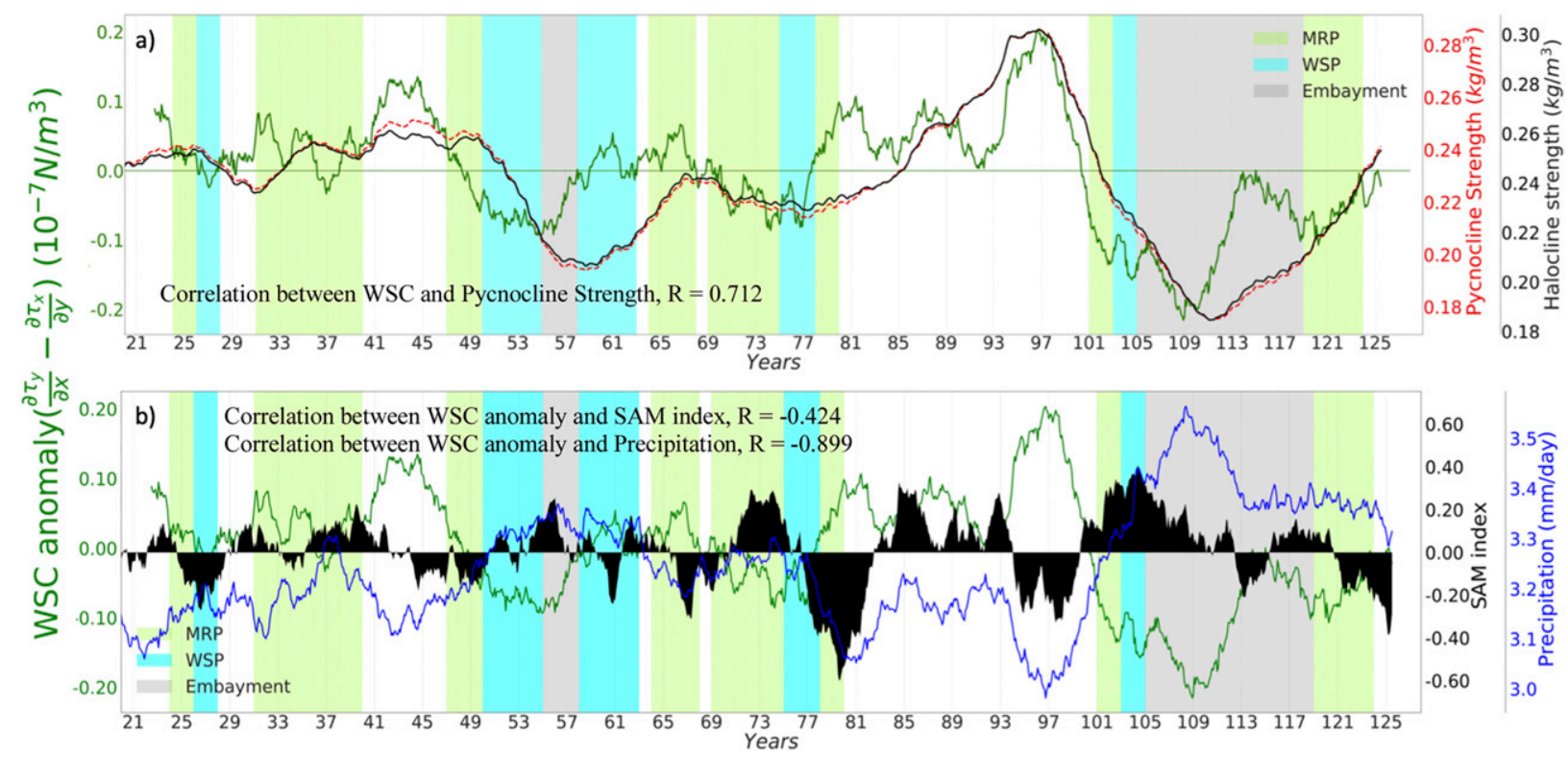

FIG. 7. (a) Time series of halocline strength (black) and pycnocline strength (red) (right-axis labels), along with wind stress curl (WSC) anomaly (green; left-axis labels). The pycnocline strength $\Delta \sigma$ and its salinity component $(\partial \sigma / \partial S) \Delta S$ or halocline strength (where $\sigma$ is potential density) were computed as the difference between $\sigma$ or $S$ at 100-200 and 0-100 m (de Lavergne et al. 2014). Values were averaged over the Weddell Sea $\left(55^{\circ} \mathrm{W}-40^{\circ} \mathrm{E} ; 50^{\circ}-70^{\circ} \mathrm{S}\right)$ and smoothed with a 5 -yr centered running average. The shading in the time series represents the type of open-ocean polynya seen during the austral winter (July-October) of the respective year (lime green: MRP; blue: WSP; gray: EMB). The WSC anomalies are computed relative to the mean monthly climatology over years 20-127. (b) Time series of a 5 -yr running mean of the monthly WSC anomaly (green), total precipitation (blue), and the SAM index (black).

Weddell Sea. Here, the SAM has been calculated following the definition of Gong and Wang (1999) as the difference between the zonal-mean sea level pressure at $40^{\circ} \mathrm{S}$ and at $65^{\circ} \mathrm{S}$. The positive trend of SAM is generally associated with southward shifted and/or intensified westerlies over the entire Southern Ocean, and vice versa (Gong and Wang 1999; Thompson et al. 1999; Marshall 2003; Hall and Visbeck 2002). In E3SMv0-HR, while the SAM is often anticorrelated with wind stress curl over the Weddell Sea, this is not always the case, possibly due to the difference in the regions considered while calculating the SAM index and the wind stress curl anomalies. The correlation coefficient between the SAM index and wind stress curl anomaly time series in Fig. $7 \mathrm{~b}$ is -0.424 with a very small $p$ value $(<0.0001)$. The correlation between the two time series are significant at $95 \%$ significance level if the $p$ value $<0.05$. The correlation coefficient between the wind stress curl anomaly time series and the precipitation (Fig. 7b) is -0.899 with a very small $p$ value $(<0.0001)$.

A time series plot of the position of the maximum zonal wind stress overlapping the wind stress curl anomaly (smoothed using a 5-yr running mean) in the Weddell Sea shows the poleward movement and anomalies of wind stress curl (Fig. 8) having a correlation coefficient of 0.71 with a very small $p$ value $(<0.0001)$. This indicates that the variability of the wind stress curl averaged over the Weddell Sea is mainly governed by the meridional position of the core of the westerlies rather than their strength.

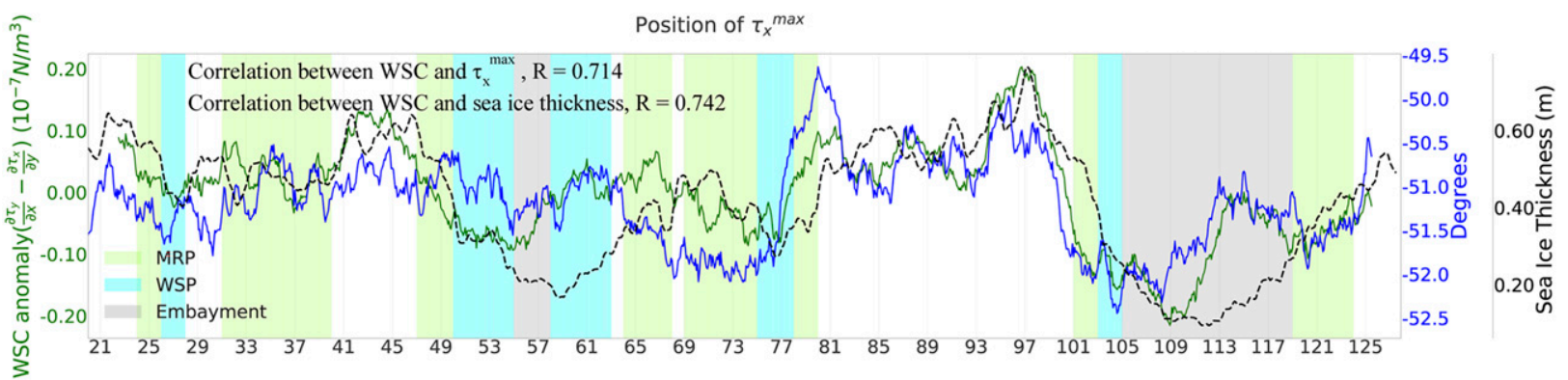

FIG. 8. Time series of annual sea ice thickness (over the region $60^{\circ}-70^{\circ} \mathrm{S}, 50^{\circ} \mathrm{W}-20^{\circ} \mathrm{E}$; black), WSC anomaly (smoothed with a 5 -yr centered running average; green), and position of the maximum zonal wind stress (smoothed with a 5-yr centered running average; blue). The shading in the time series represents the type of open-ocean polynya seen during the austral winter of the respective year (lime green: MRP; blue: WSP; gray: EMB). 
a)

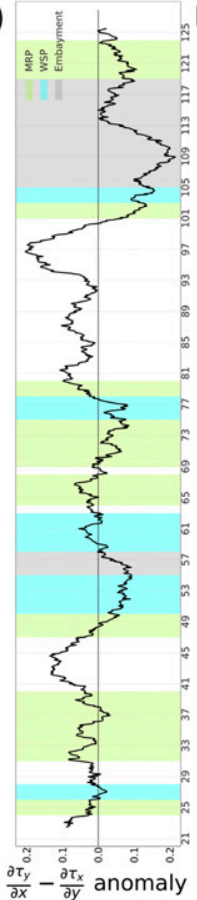

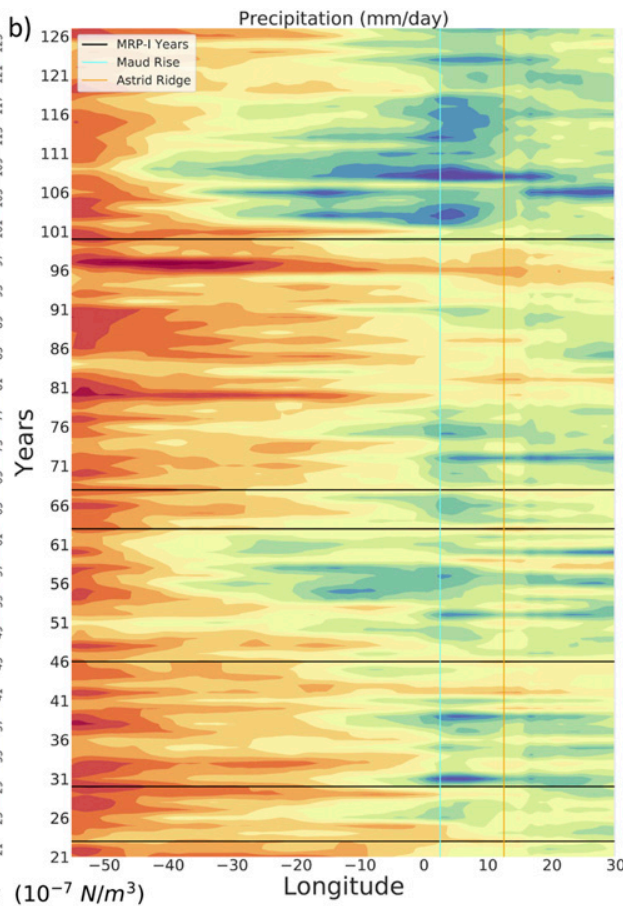

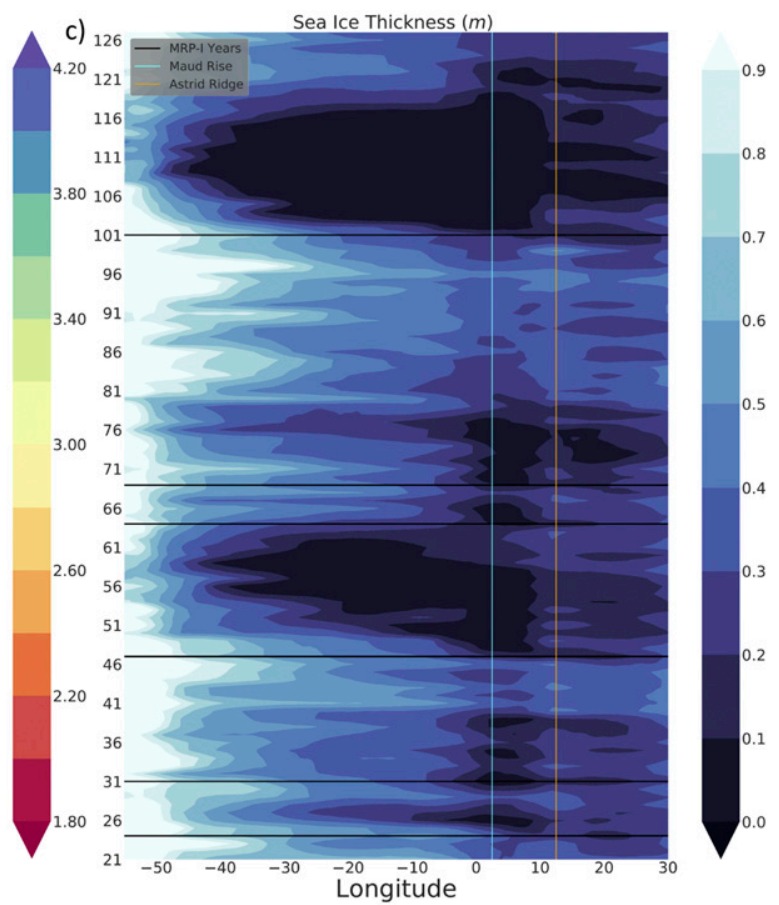

FIG. 9. (a) Time series of WSC anomalies (as in Fig 7b, but repeated here for comparison with other panels), and Hovmöller diagrams of annual averaged (b) precipitation and (c) sea ice thickness, meridionally averaged over the region $64^{\circ}-68^{\circ} \mathrm{S}$. The horizontal black lines refer to all of the "MRP-I" years in E3SMv0-HR. The blue and orange vertical lines indicate the longitudes of Maud Rise seamount and Astrid Ridge, respectively.

A Hovmöller diagram of precipitation averaged meridionally over the $64^{\circ}-68^{\circ} \mathrm{S}$ band is presented in Fig. $9 \mathrm{~b}$ and shows the presence of high precipitation areas over and downstream of polynyas forming during polynya years. The largest precipitation values (blue areas in Fig. 9b) over Maud Rise and the Weddell Sea are seen during years with low winter sea ice thickness (Fig. 9c) and only over polynyas. It can therefore be concluded that the increase in precipitation is associated with rising motion of moist and relatively warm air over polynyas, as found in Weijer et al. (2017), reflecting a direct response to the heat loss in association with the ventilation of WDW in open-ocean polynyas. Gordon (2014) argues that drier conditions over the Weddell Sea favor the formation of WSPs. As indicated in Fig. 9, our simulation does not support this hypothesis as drier conditions mostly coincide with thicker ice. In conclusion, the model results show that a more negative wind stress curl (Fig. 9a) has a stronger impact on initiating winter convection and WSP formation than drier atmospheric conditions.

The positive (negative) phase of the SAM index is to some extent associated with a more southern (northern) position of the Southern Hemisphere westerlies (see Fig. 8; Hall and Visbeck 2002), which leads to more (less) precipitation as well as intensified (reduced) cyclonic wind stress curl anomalies over the Weddell Sea (Gordon 2014; Gordon et al. 2007). In E3SMv0HR, the correlation between the position of the maximum zonal wind stress (Fig. 8) and SAM index (Fig. 7b) is -0.6 with a very small $p$ value $(<0.0001)$. These two variables have opposing effects on the stratification of the Weddell Sea: on the one hand, a cyclonic wind stress curl leads to a spinup of the cyclonic Weddell Gyre, thereby weakening the stratification in its centers as a result of a more pronounced doming of isopycnals; on the other hand, the concomitant increase in precipitation will lower the surface density by freshening and thereby strengthen the stratification. The negative phase of the SAM index is associated with the core of the precipitation-rich westerlies being located farther north than on average, which leads to drier atmospheric conditions as well as diminished negative (or less cyclonic) wind stress curl anomalies over the Weddell Sea. The westerlies being located at a northward position allows the northward expansion of dry polar air masses over the Weddell Sea, which makes the surface layer saltier and denser, thereby weakening the stratification; on the other hand, the associated positive (or less cyclonic) wind stress curl anomalies would lead to a spindown of the Weddell Gyre that deepens the isopycnals in its center thereby increasing stratification. In E3SMv0-HR, the spinup of the cyclonic Weddell Gyre plays a more influential role in the formation of open-ocean polynyas than the northward expansion of dry atmospheric conditions in the Weddell Sea. Additionally, the SAM index does not always capture the negative wind stress curl anomalies in the Weddell Sea.

\section{c. Role of surface salinification in weakening the stratification in the Weddell Gyre}

To visualize the impact of the salinity preconditioning of the Weddell Sea on local stratification over the MR-AR complex as well as upstream of it, we compare meridional cross sections of 


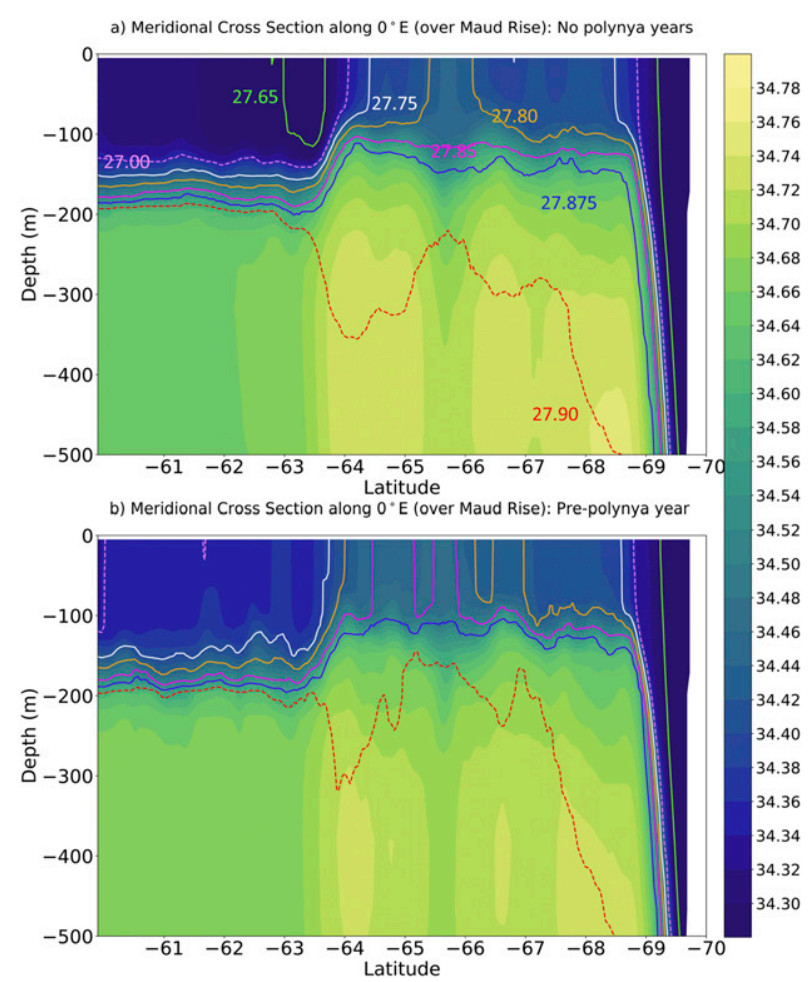

FIG. 10. September salinity in the central Weddell Sea along $0^{\circ}$ during the (a) no-polynya years 41-45 and 82-96 and (b) "MRP-P" years that precede the MRP+WSP years in E3SMv0-HR. The colored contours are density.

September salinity and density along $0^{\circ}$ (western flank of Maud Rise; Fig. 10) and $30^{\circ} \mathrm{E}$ (upstream and east of MR-AR; Fig. 11) for a) the years with no polynyas and $b$ ) the year with no polynya just prior to the onset of MRP+WSP years. The upper $100 \mathrm{~m}$ is saltier, and denser isopycnals outcrop at the surface in Fig. 10b when compared to Fig. 10a. In other words, there is a very weak stratification in the upper $200 \mathrm{~m}$ along $0^{\circ}$ in the winter preceding MRP+WSP years. The same is true for the meridional cross section at $30^{\circ} \mathrm{E}$ (Fig. 11). The meridional cross section at $20^{\circ} \mathrm{W}$ (not shown) is also consistent with these findings. The stronger doming of the isopycnals indicates large-scale preconditioning prior to the MRP+WSP years. Anomalously salty water at the surface could indicate entrainment of WDW into the upper $200 \mathrm{~m}$ layer of the Weddell Sea.

\section{d. Role of high sea surface salinity from large MRPs in triggering WSPs}

The preindustrial E3SMv0-HR simulation produces both small and large MRPs as characterized by the size of the sea ice-free area of the polynya. MRPs preceding the MRP+WSP years are significantly larger than the MRPs in the MRP years. However, it is not clear why some MRPs develop into WSPs (e.g., those that occur in years 47-62), whereas other MRPs do not (e.g., those that occur in years 31-39).

The zonal cross section along $65^{\circ} \mathrm{S}$ of the winter averaged salinity and density before and during an MRP are used to

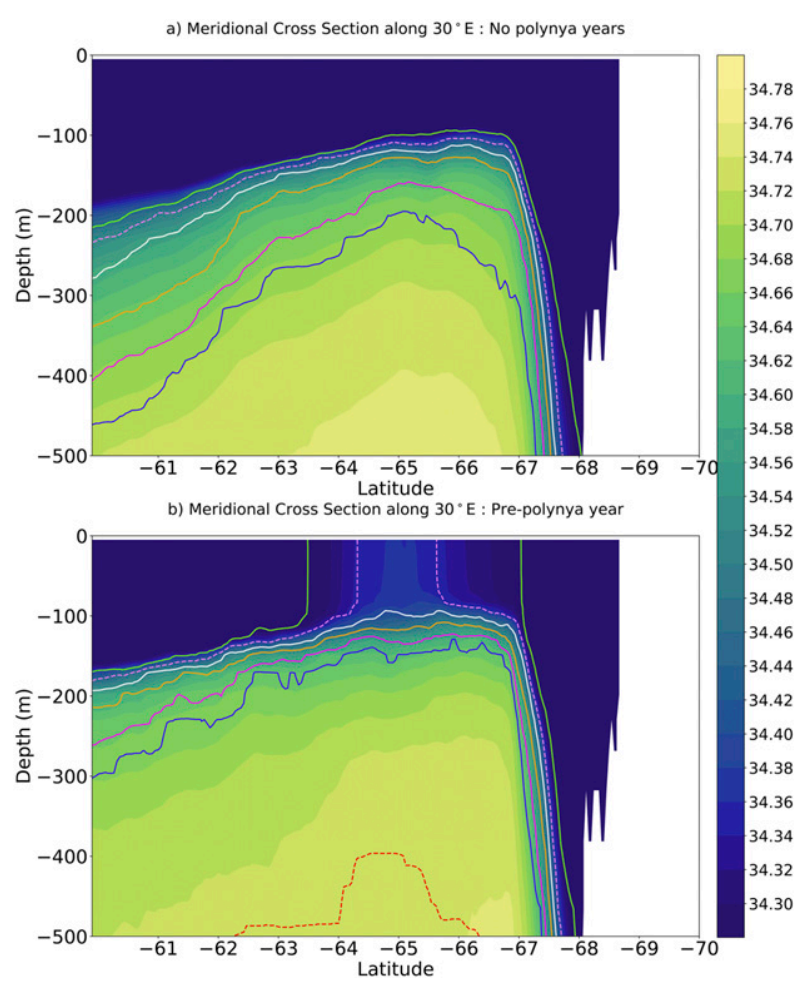

FIG. 11. As in Fig.10, but in the eastern Weddell Sea along $30^{\circ} \mathrm{E}$. The colored contour values are consistent with Fig. 10.

visually characterize the extent of mixing that occurs over the MR-AR bathymetric complex. We can compare the zonal cross sections just before and during MRPs from an instance in the MRP years (years 30, 31, and 35 in Fig. 12) with those of an instance in the MRP+WSP years (years 46, 48, and 50 in Fig. 13). The MRPs during the MRP+WSP years bring up more salt into the surface layer than those occurring during the MRP years. The potential density contour indicated by the red line in Figs. 12 and 13, which lies in the center of the WDW salinity maximum, is used here to indicate WDW. The outcropping of WDW at the surface occurs over a significantly larger area in the MRP in the MRP+WSP years (year 48 in Fig. 13) than in MRP years (year 35 in Fig. 12; no outcropping at all in year 31), which suggests that larger salinity anomalies are introduced at the surface ocean. In this sense, we can define MRPs that precede MRP+WSP years as "strong."

The increase in the surface salinity through ventilation of WDW over Maud Rise due to a strong MRP allows for the surface layer downstream of it to destabilize, thus creating WSPs in the following winters. The strong convection over Maud Rise in year 50 (Fig. 13c) continues during the subsequent WSP years. Year 50 is a WSP year, as can be confirmed from the insert of Fig. 13c, showing that deep mixed layers extend to $20^{\circ} \mathrm{W}$. Thus, while high surface salinity waters spread westward downstream from Maud Rise with the flow of the Weddell Gyre, convection over Maud Rise stays active and continues to introduce WDW into the upper $100 \mathrm{~m}$. Comparing the area of the winter maximum mixed layer depth greater than $2000 \mathrm{~m}$ in MRPs in 
a) Zonal Cross Section along $65^{\circ} \mathrm{S}$ : Year 30 (MRP-P winter)
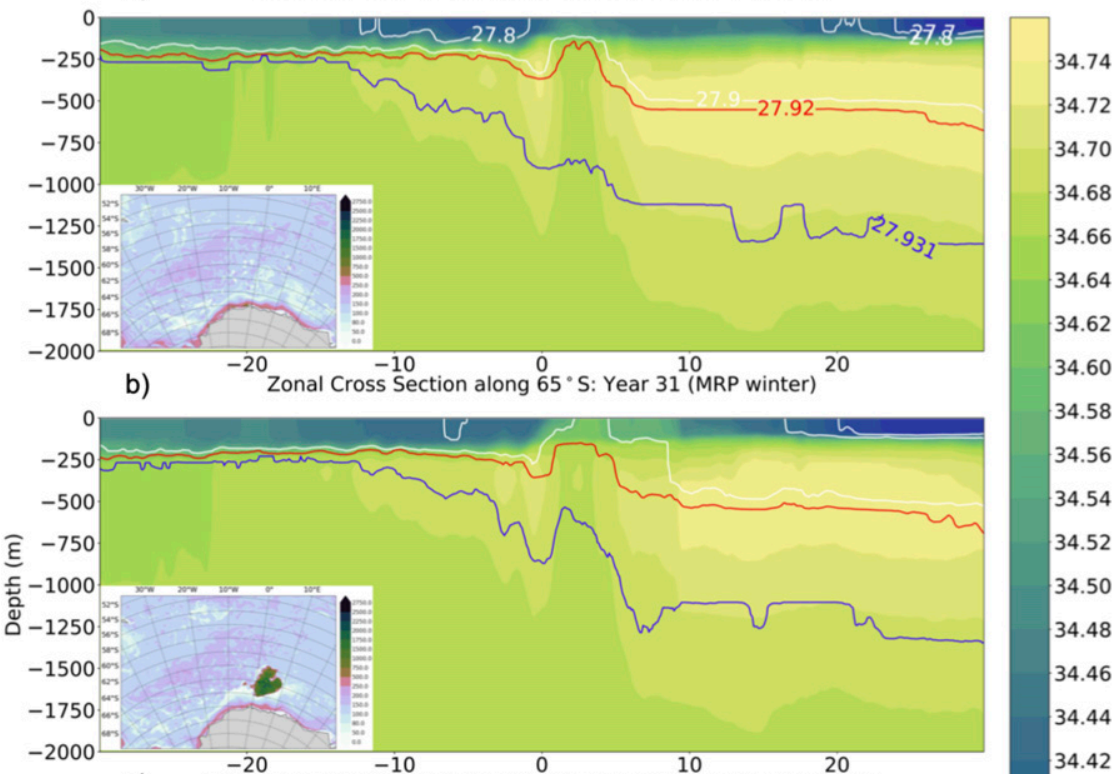

c) Zonal Cross Section along $65^{\circ} \mathrm{S}$ : Year 35 (subsequent MRP winter)

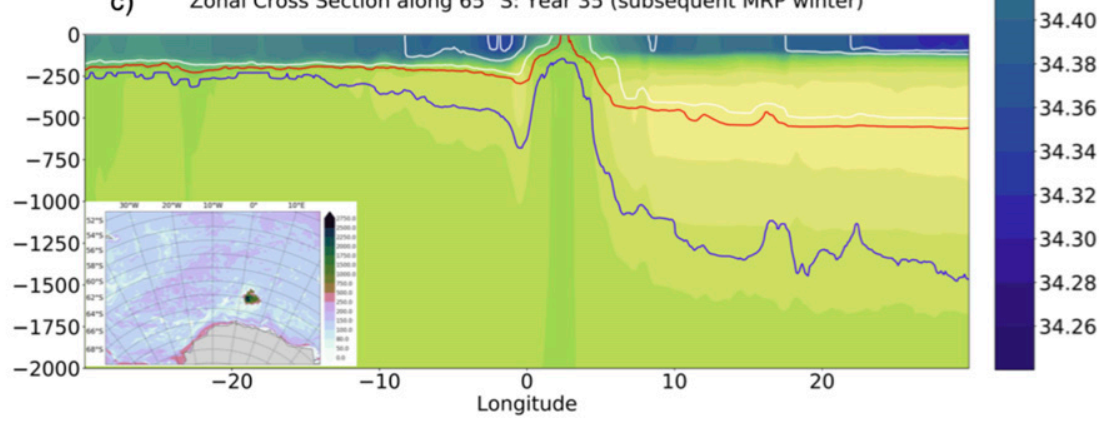

FIG. 12. Zonal cross section of winter (July-October) salinity and density contours averaged over the $64^{\circ}-66^{\circ} \mathrm{S}$ region, before and during one instance of the MRP case, i.e., years 31-39. Shown are (a) the MRP-P year 30 (pre-polynya), (b) the MRP year 31, and (c) the subsequent MRP year 35. The colored contours indicate potential density. The inset in each figure shows the maximum mixed layer depth in September of the corresponding year.

the MRP+WSP years with that of MRPs in the MRP years, we find that only very large MRPs provide high enough upper-ocean salinity anomalies, which then give rise to WSPs. This also holds for the other cases of MRP+ WSP years of the simulation.

To visualize the magnitude of the anomalous salinity introduced by WDW in the upper $200 \mathrm{~m}$, we generate a time series of average salinity over the Maud Rise seamount during MRPs (Fig. 14). We enlarge the upper $200 \mathrm{~m}$ (upper panels of Figs. $14 a, b)$ to clearly compare the upper-ocean salinity during an instance in the MRP years (years 31-39; Fig. 14a) with an instance in the MRP+WSP years (years 47-62; Fig. 14b). The upper-ocean salinity during the latter instance (Fig. 14b, upper panel) is clearly much larger than that during the former instance (Fig. 14a, upper panel). The lower panels of Figs. 14a and 14b show the depletion of WDW during open-ocean polynyas indicating that this loss is more thorough during the MRP+WSP years. Convection over Maud Rise stays active during the WSPs following year 50 , thus supplying the necessary surface salinity anomalies needed to destabilize the water column downstream.
The reinforcement of upper-ocean temperature and salinity anomalies due to convection over the MR-AR bathymetric complex can readily be seen in Fig. 15, displaying the evolution of upper $100 \mathrm{~m} T$ and $S$ over years 21-127. Anomalously strong MRPs (associated with anomalously warm and salty upper-ocean conditions over the MR-AR bathymetric complex) precede the destabilization of the central Weddell Sea, and this process is associated with a gradual westward propagation of upper-ocean temperature and salinity anomalies. This happens in MRP+WSP years $47-62,68-80$, and 101-118 where large positive anomalies appear between the regions of Maud Rise (vertical red line) and Astrid Ridge (vertical white line), which then spread westward in subsequent years, leaving their imprint on sea ice in the form of WSPs.

A necessary but not sufficient condition for long-lasting, consecutive winter WSPs to occur is the heat reservoir at depth, or the heat content of WDW (Martinson et al. 1981; Martin et al. 2013; Cheon et al. 2015; Dufour et al. 2017). Once the switch is made from stable to convective mode, the heat content of WDW in the 
a) Zonal Cross Section along $65^{\circ} \mathrm{S}$ : Year 46 (MRP-P winter)

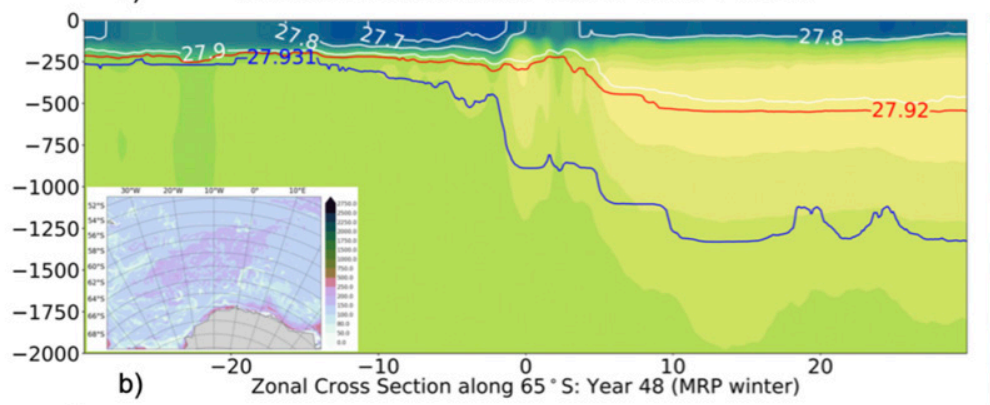

b)

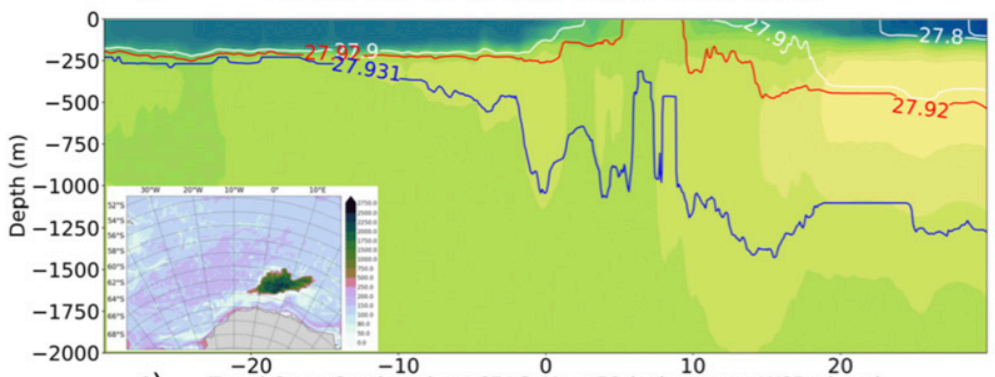

c) Zonal Cross Section along $65^{\circ} \mathrm{S}$ : Year 50 (subsequent WSP winter)

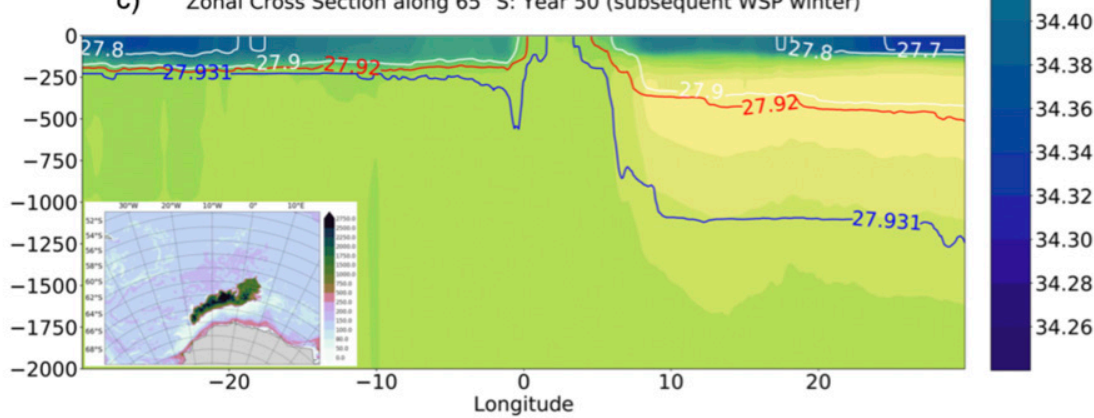

FIG. 13. As in Fig. 12, but for an instance of the MRP+WSP case (i.e., years 101-123): (a) the MRP-P year 46 (pre-polynya), (b) the MRP year 48, and (c) the subsequent WSP year 50.

vicinity of Maud Rise plays another dominant role in maintaining the WSP by supplying the heat needed to prevent sea ice formation. Since the WSP mode is associated with deep-penetrating convection, it drastically reduces the subsurface WDW heat content thus ventilating the subsurface ocean. The temperature averaged over the WDW layer $(250-1000 \mathrm{~m})$ is presented in Fig. 16 and shows a regional cooling of more than $1^{\circ} \mathrm{C}$ during WSPs. Deep convection during the MRP + WSP years also affect the salinity of WDW by introducing surface freshwater into the deeper layers, thus reducing WDW salinity during the WSP events. A prolonged period of recovery of WDW heat and salt content is thus an important preconditioning for sustaining WSPs. Such periods emerge in the years prior to the MRP+WSP years (e.g., years 80100; Fig. 16a). In E3SMv0-HR, the time span when the subsurface heat builds up coincides with positive wind stress curl anomalies in the Weddell Sea, leading to a deepening of isopycnals in its center and a more stable stratification that allows for a recharge of the subsurface heat reservoir (e.g., Dufour et al. 2017).

We thus propose the following mechanism: when a strong MRP is triggered over Maud Rise, the ensuing deep convection erodes the weak stratification over it and brings up WDW into the winter mixed layer, which then flows downstream into the central Weddell Sea. Since the stratification in the Weddell Sea is more stable (Fig. 13) than that over Maud Rise (due to the Taylor cap dynamics over it), one way to trigger the convective mode in the Weddell Sea is by introducing salinity anomalies into the winter mixed layer that are high enough to erode the stratification of the Weddell Sea. The high salinity anomalies provided by WDW during the MRPs of MRP+WSP years are large enough to trigger convection downstream, thus allowing for the switch from a stable mode to a convective mode in the central Weddell Sea, beyond the region of Maud Rise, hence leading to the formation of a full-scale WSP (see the online supplemental material for an animation of monthly maximum mixed layer depth of E3SMv0-HR).

\section{e. Evolution of convection using salinity as a tracer}

The initiation and development of convection over Maud Rise is further scrutinized by analyzing daily model output that was stored for a short period of the E3SMv0-HR simulation, in 


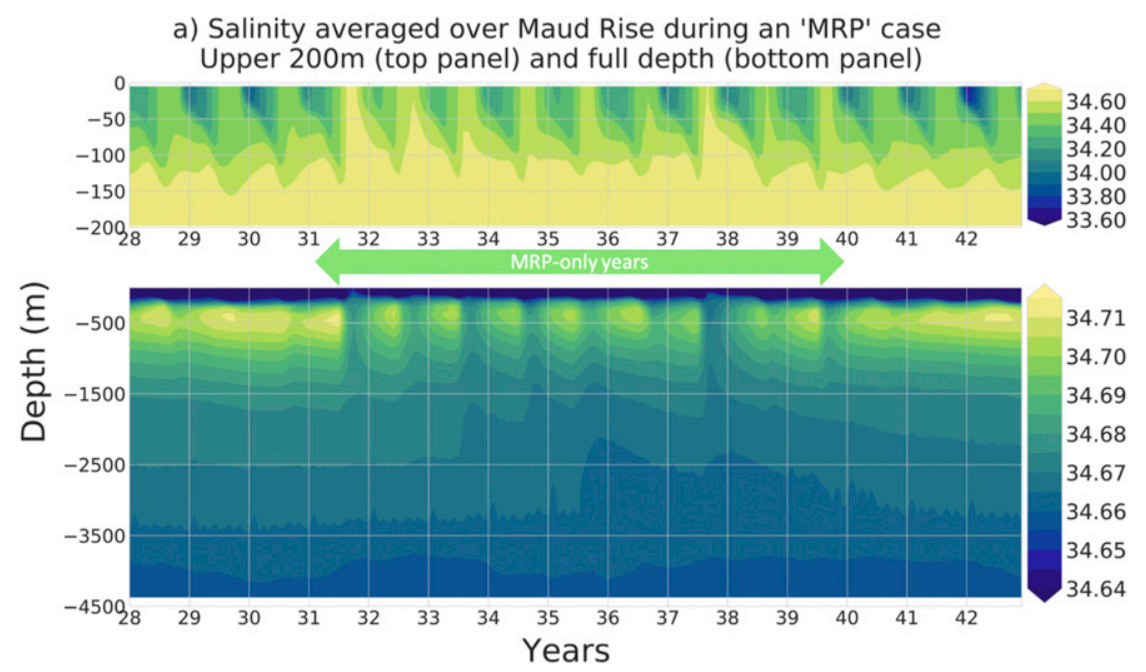

b) Salinity averaged over Maud Rise during an 'MRP+WSP' case Upper $200 \mathrm{~m}$ (top panel) and full depth (bottom panel)

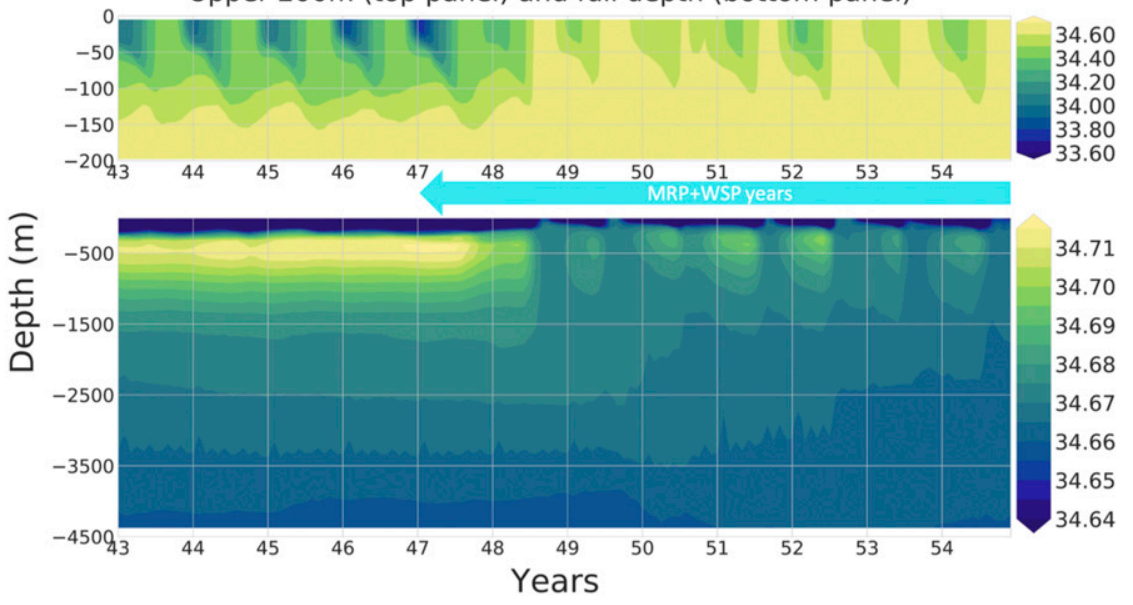

FIG. 14. Time series of monthly salinity depth profiles averaged over the Maud Rise seamount from years 28 to 54 that include (a) the MRP case (years 31-39) and (b) the MRP+WSP case (years 47-54). Note that we use a different color-bar range for the plots of the upper $200 \mathrm{~m}$ and full depth.

order to study short-term features that cannot be properly identified in the monthly data. In particular, daily data were stored during years 35-37, during which MRPs occurred. The onset of deep convection can be followed by studying the individual terms of the advection-diffusion equation given in Eq. (1), for any $\operatorname{tracer} \theta$ :

$$
\underbrace{\frac{\partial \theta}{\partial t}}_{\text {rate }}=-(\underbrace{u \frac{\partial \theta}{\partial x}+v \frac{\partial \theta}{\partial y}}_{\text {horizontal advection }})-\underbrace{w \frac{\partial \theta}{\partial z}}_{\text {vertical advection }}+\{\underbrace{\left(\frac{\partial^{2}}{\partial x^{2}}+\frac{\partial^{2}}{\partial y^{2}}\right)\left[K_{H}\left(\frac{\partial^{2}}{\partial x^{2}}+\frac{\partial^{2}}{\partial y^{2}}\right)(\theta)\right]}_{\text {herizontal mixing }}\}+\underbrace{\frac{\partial}{\partial z}\left(K_{V} \frac{\partial \theta}{\partial z}\right)}_{\text {vertical mixing }}+\underbrace{F}_{\text {forcing }}
$$

where $K_{H}$ and $K_{V}$ are the horizontal and vertical eddy diffusivity, respectively; $u, v$, and $w$ are the ocean velocity components; and $F$ represents external sources and sinks of $\theta$ (forcing). The dominant terms in the tracer equation for salinity were computed over an area of $10 \mathrm{~km}$ by $10 \mathrm{~km}$ (located at $67.0^{\circ} \mathrm{S}, 1.0^{\circ} \mathrm{E}$ ) of the upper $500 \mathrm{~m}$, in a region where deep convection appears first, and subsequently leads to a mature MRP. The stratification in the box goes from being stably stratified to fully convecting in a matter of days. Note that, while the resolution of the model is insufficient to resolve convective plumes $[O(\sim 0.5-1 \mathrm{~km})]$ and is crudely parameterized, it can resolve convecting chimneys (regions where density is nearly homogeneous 
Temperature $\left({ }^{\circ} \mathrm{C}\right)$ Upper $100 \mathrm{~m}$

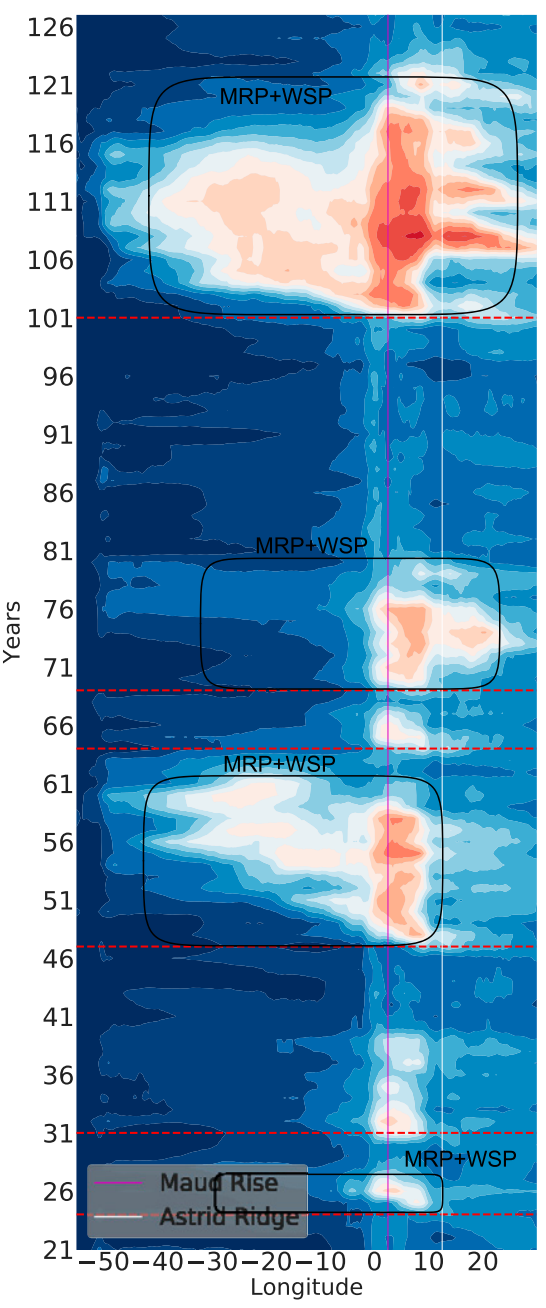

Salinity (psu) Upper 100m

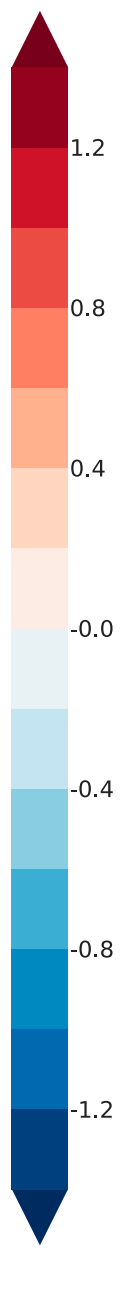

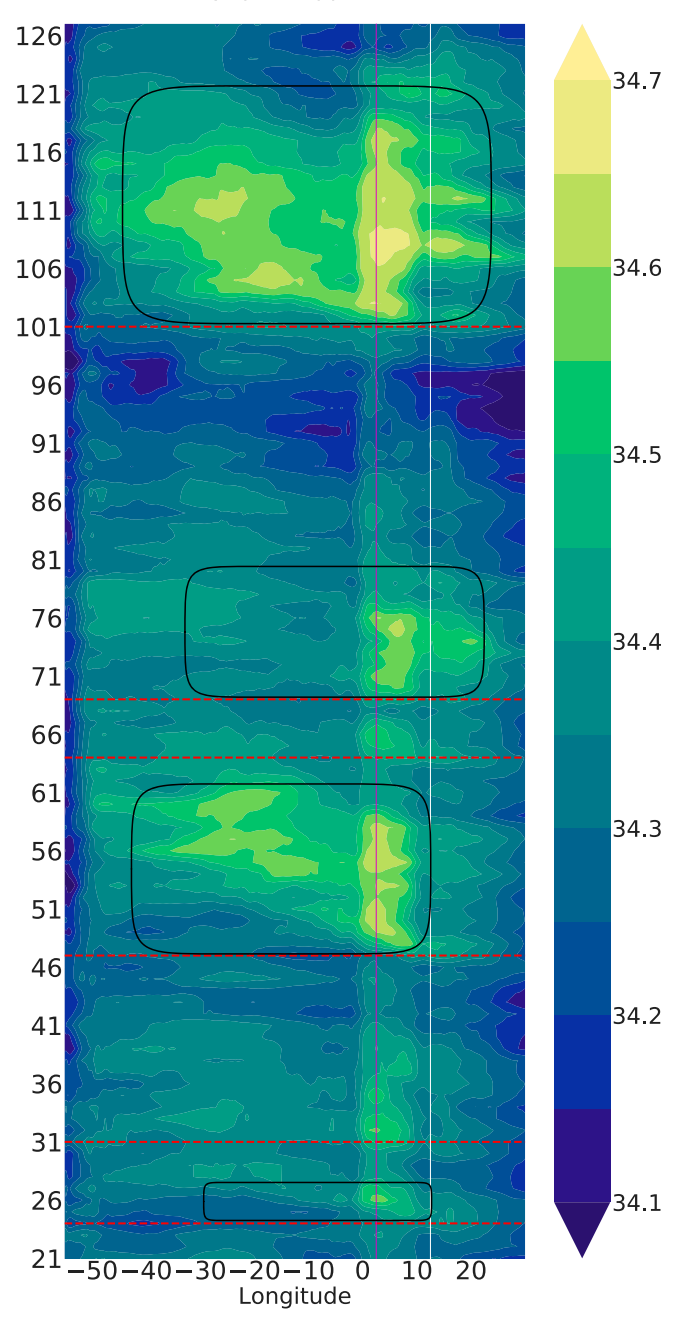

FIG. 15. Hovmöller diagrams of the upper-100-m monthly (left) potential temperature and (right) salinity averaged over the $64^{\circ}-68^{\circ} \mathrm{S}$ region for years $21-127$. The horizontal dashed lines refer to all of the "MRP-I" years in E3SMv0-HR. The rectangular-outlined boxes show the MRP+WSP years.

with depth), which have been observed in the ocean and can span tens of kilometers in width (Marshall and Schott 1999).

A Hovmöller time series of the dominant terms in the tracer equation for salt, averaged in a $10-\mathrm{km}^{2}$ area over Maud Rise, is shown in Fig. 17 and is focused around the time when an MRP is triggered in year 37. The change in salinity (Fig. 17a) is analyzed by tracking total (horizontal plus vertical) advection (Fig. 17b), vertical mixing (Fig. 17c), and horizontal mixing (Fig. 17d) over the same region. Figure 17a indicates that salinity in the upper $100 \mathrm{~m}$ begins to increase noticeably between days 35 and 40 . The positive values in vertical mixing during the same time in the upper $200 \mathrm{~m}$ indicate salinity being added to this layer while the negative values at depth indicate freshening. After intense mixing between days 35 and 40, the upper500 -m salinity remains homogeneous until $\sim$ day 65 . The daily maximum mixed layer depth shows intermittent large values higher than $500 \mathrm{~m}$ in May and June of year 37 meandering between grid cells, but it does not show up in the monthly averaged maximum mixed layer depth data (not shown). The convective chimney in essence meanders between grid columns and repeats the process described above. These features are discernable only in the daily data of E3SMv0-HR, and the process is similar to that described by Marshall and Schott (1999).

\section{Discussion and conclusions}

This paper investigates the processes that explain the occasional westward expansion of MRPs into larger WSPs as observed in the winter sequence of the mid-1970s, and to some extent also represented in the preindustrial high-resolution coupled E3SMvo-HR simulation analyzed here. While capturing various characteristic features that drastically improve the simulation of critical processes for AABW formation, E3SMv0-HR does not fully resolve mesoscale eddies in the 

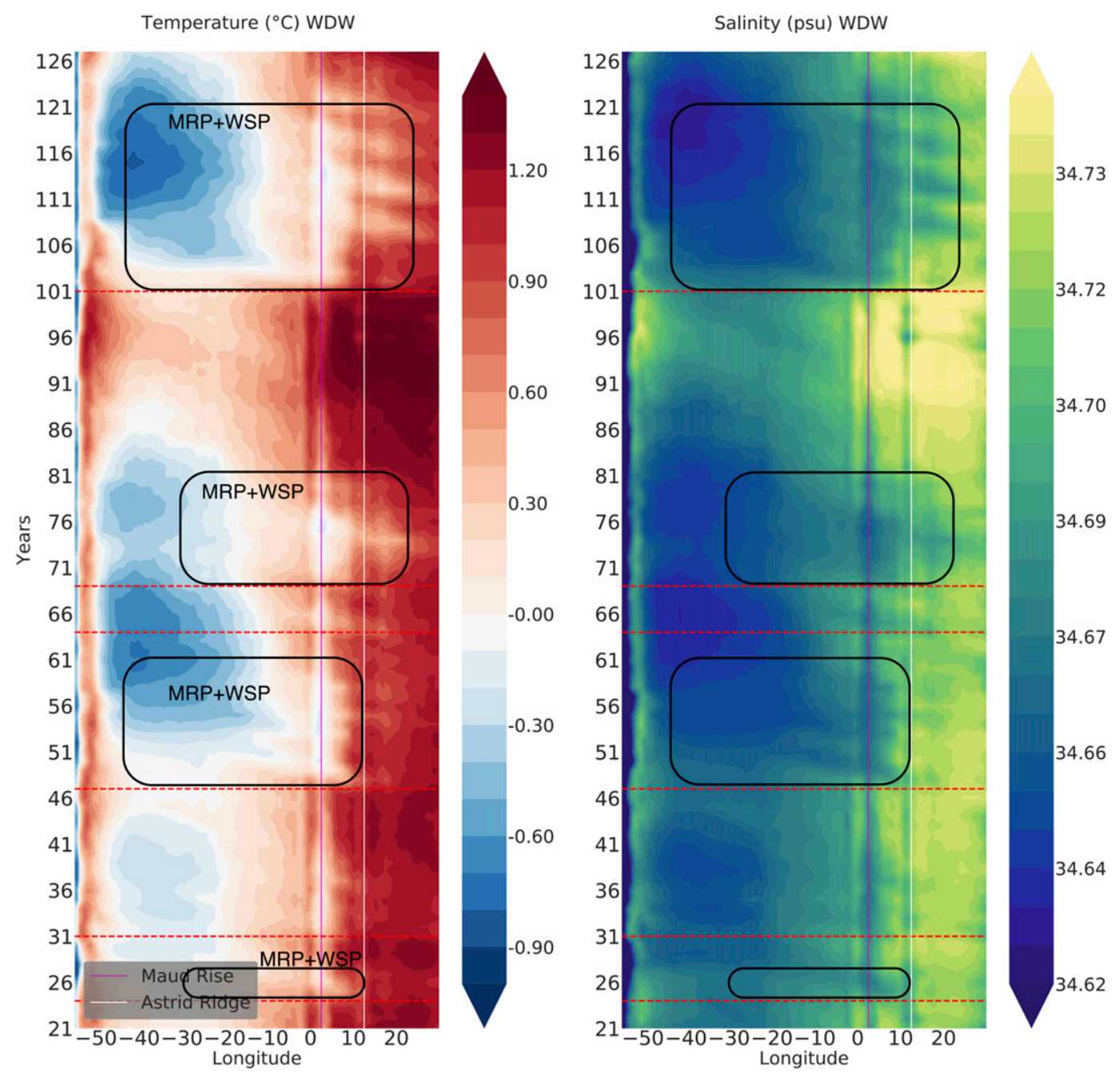

FIG. 16. As in Fig. 15, but for the 250-1000-m depth range (the core of the WDW water mass).

high-latitude Southern Ocean, in particular not on the continental shelves (see, e.g., Hallberg 2013). Another limitation arises from the relative shortness of the simulation (130 years) when compared with the number of unique simulated WSP events (2-3), which does not allow for a meaningful statistical analysis. Last, and as also noted in Small et al. (2014), 130 years is far too short a time for the deep ocean to adjust to the new surface boundary conditions of the coupled system, thus leading to the notorious issue of model drift. Any of our conclusions from this study must thus be interpreted against the background of these limitations.

A synthesis of our findings has been visually rendered in the form of a schematic in Fig. 18. The first panel of the schematic (Fig. 18a) describes conditions around Maud Rise that are typical for no-polynya years: a generally well-stratified Weddell Sea, due to the presence of the fresh and cold Antarctic Surface Water (ASW) in the upper $200 \mathrm{~m}$ of the water column, but also a weakly stratified Taylor cap over Maud Rise, which is associated with a northern deflection of the flow impinging onto the seamount and a cyclonic flow directly over the seamount. These findings are supported by theoretical, modeling, and observational studies (de Steur et al. 2007; Gordon and Huber 1990; Alverson and Owens 1996; Muench et al. 2001; Kurtakoti et al. 2018; Campbell et al. 2019). The schematics in Figs. $18 \mathrm{~b}$ and $18 \mathrm{c}$ represent the onset of MRPs as understood in Kurtakoti et al. (2018): a westward advection of anomalously high surface salinities over the MRAR complex, combined with a further weakening of the ocean stratification (compared to the no-polynya conditions of Fig. 18a) through Taylor column dynamics, and eventual trigger of a convective mode. Once deep convection ensues, WDW is brought up to the surface and the heat content of this water mass keeps the polynya region ice-free by hindering sea ice formation, leading to an MRP. E3SMv0-HR is also able to resolve meandering short-lived convective chimneys in MRPs, which can only be visualized using daily rather than monthly averaged data.

In addition to surface temperature, the ventilation of WDW also impacts surface salinity, and the associated high salinity anomalies are expected to be advected downstream into the 


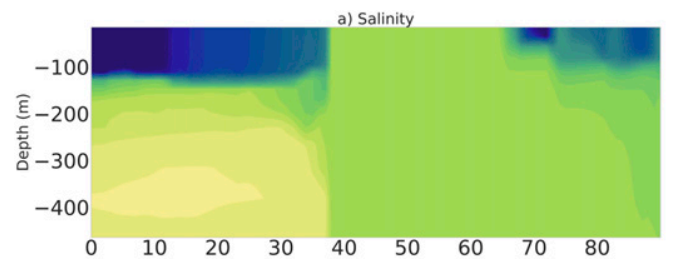

34.69

34.66

34.63
34.60

34.57

34.54
34.51

34.48
34.45

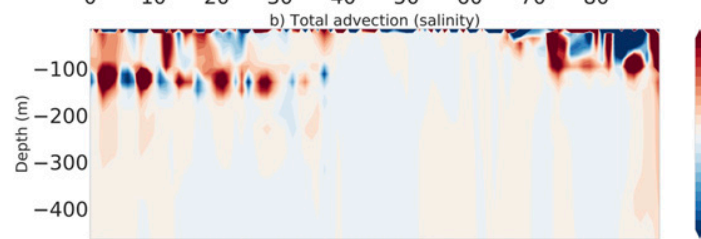

$\mathrm{g} / \mathrm{kg} / \mathrm{s}$

0.009

0.006

0.003

0.000

$-0.003$

-0.006
-0.009

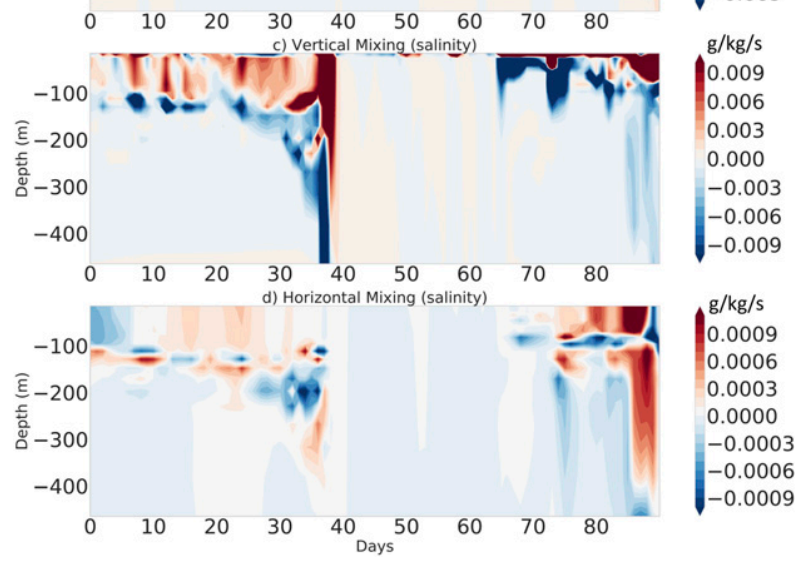

FIG. 17. Time series of (a) salinity, (b) total advection, (c) vertical mixing (diffusion), and (d) horizontal mixing over Maud Rise in a box of $10 \mathrm{~km} \times 10 \mathrm{~km}$ just before and after convection begins within the box during June-August of year 37, using daily model output from E3SMv0-HR. Note that we use a different color-bar range for (d) than that in (b) and (c).

central/western Weddell Sea following the gyre circulation (Fig. 18d). Our results suggest that, for this scenario to eventually convert itself into a greater WSP during the following winter season, two factors need to coexist, and they are both represented in the schematic in Fig. 18e. Since the stratification in the central Weddell Sea is stronger than that over the MR-AR complex, in order to trigger convection west of Maud Rise significantly larger upper-ocean salinity anomalies are needed there to initiate convection than would be necessary to trigger MRPs. We argue that these high-salinity anomalies are provided by anomalously large MRPs: the size of the MRP dictates the scale of open-ocean convection over the MR-AR complex, which in turn determines the amount of salt from WDW brought to the upper ocean. Indeed, we find that the size of ice-free MRPs in "MRP+WSP" years is much larger than that of "MRP" years (see definitions at the end of section 2). In addition to this, we also argue that an important factor for the formation of large WSPs is a long-term (over several years) trend from positive to negative wind stress curl anomalies (Fig. 7a). The associated spinup of the double-cell Weddell Gyre leads to a doming of isopycnals that weakens the ambient stratification in both the central and eastern Weddell cell, although more so in the former. This amplifies the entrainment of WDW into the upper ocean along the eastern end of the eastern cells, possibly one of the reasons contributing to higher salinity anomalies that are being advected downstream (Fig. 18d). While it is well established that the spinup of the Weddell Gyre is an important factor for the formation of open-ocean polynyas in the Weddell Sea, it is here put into context with the surface salinification/weakening of the stratification mechanisms that are also often invoked for WSP formation. It should also be noted that in E3SMv0-HR the response of the Weddell Gyre to wind stress curl changes over the Weddell Sea is mostly delayed by several years and is not as obvious as typically simulated in low-resolution models and with ("clean") specified changes of the strength of the westerlies (e.g., Cheon et al. 2014). The delay is likely due to more intensive interaction of the flow with the higher-resolution bathymetry, the effect of resolved mesoscale eddies, and their interaction with bathymetry. Insights into the complex dynamics of the Weddell Gyre and its response to varying wind stress are given by, for example, Su et al. (2014).

Since E3SMv0-HR is a preindustrial simulation, it does not represent, in principle, the processes associated with anthropogenic effects that are typically used to justify the inhibition of open-ocean polynyas in the present-day Weddell Sea (e.g., de Lavergne et al. 2014). However, the observed wind stress curl using ERA-5 (0.25 spatial resolution) data (Copernicus Climate Change Service 2017) calculated over the Weddell Sea during the 2017 MRP (Fig. 19b) is less negative than that simulated in the MRP+WSP years in E3SMv0-HR (Fig. 19a). Similarly, wind stress curl anomalies computed from atmospheric reanalysis data during the 2016 and 2017 MRPs (Cheon and Gordon 2019; their Fig. 4) are less negative than those in MRP+WSP years. The observed wind stress curl reached anomalously negative values in 2016 and 2017 but since then has weakened (Fig. 19b). It is possible to explain the lack of an MRP in 2018 due to weakened cyclonic wind stress curl (Fig. 19b). The observed wind stress curl during 2018 was less negative than in 2016. Our findings reveal that not all MRPs, observed and modeled, develop into WSPs. We speculate that a sustained intensification of the Weddell Gyre is most likely a necessary condition for MRPs to be followed by WSPs.

In summary, critical factors for MRPs to transition into WSPs are the wind stress curl over the Weddell Sea, the upperocean pycnocline strength, the buildup of a heat reservoir at depth, and, most importantly, high upper-ocean salinity anomalies in association with pronounced MRPs that will enable winter convection to spread into the western Weddell Sea where they eventually trigger WSPs. The period of intense deep convection in the Weddell Sea following a WSPs contributes to dense water formation and gives rise to AABW anomalies (below 4000-m depth; not shown), which propagate along the deep western boundary into the Atlantic Ocean (Fig. 18f).

An additional conclusion of this study is that anomalous salinities introduced in the surface ocean upstream of the MRAR complex are not explained by anomalous surface freshwater fluxes due to atmospheric exchanges or sea ice melting/ forming over that region. In E3SMv0-HR, we only see anomalously high precipitation as a consequence of heat released into the atmosphere due to open-ocean polynyas. Other 

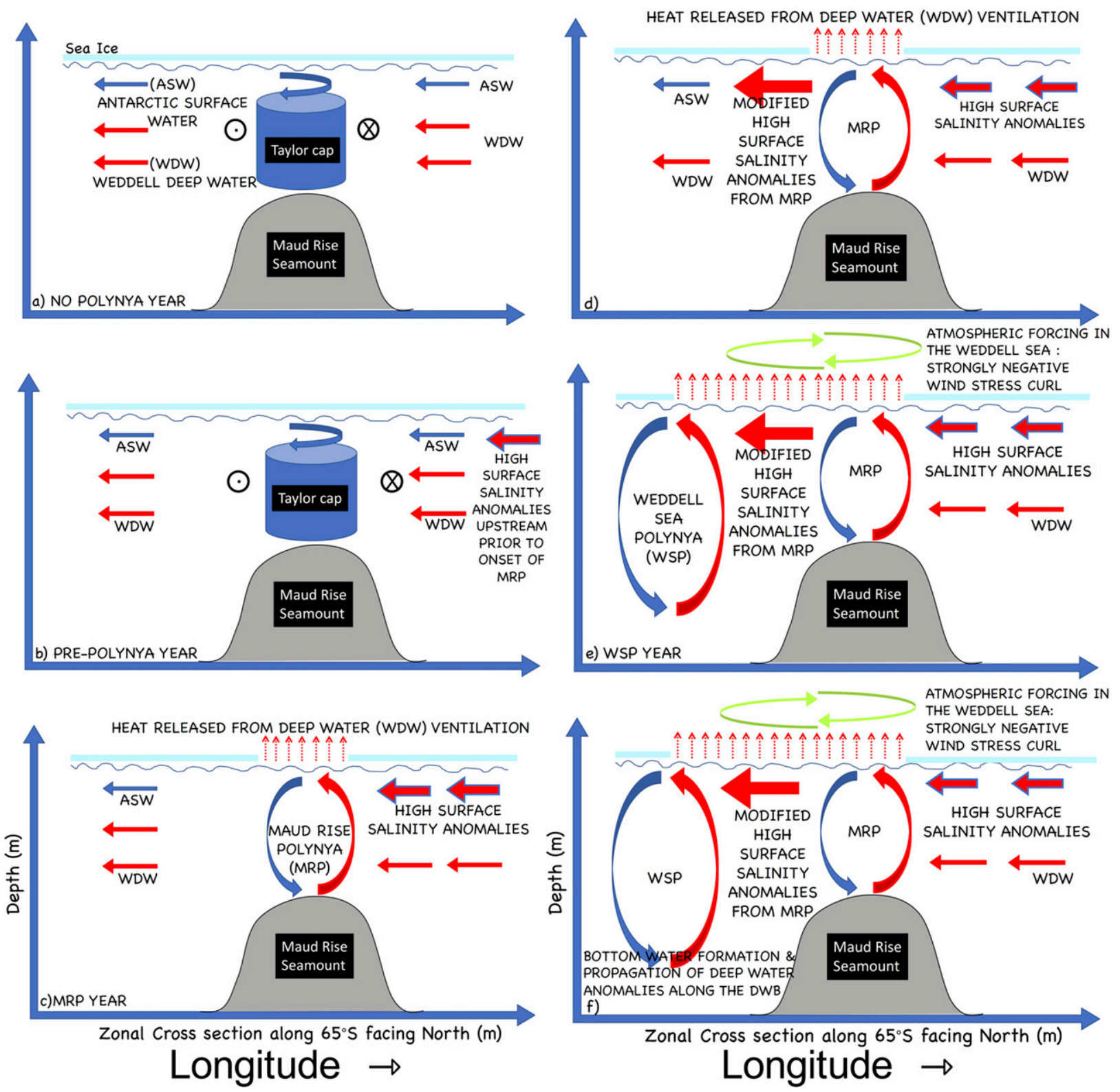

FIG. 18. A schematic summarizing the processes necessary for the formation of (left) MRP and (right) WSP. (a) Factors that affect the stratification over Maud Rise. (b) Factors preceding an MRP. (c) Factors describing the formation of an MRP. (d) Factors describing the consequences of an MRP. (e) Factors describing formation of a WSP following an MRP. (f) Factors describing the impacts of WSP on the deep ocean.

factors, including the spinup of the Weddell Gyre described above or processes such as storms and polar cyclones (Francis et al. 2019; Jena et al. 2019; Wilson et al. 2019) seem to be more relevant for the introduction of surface salinity anomalies into the Maud Rise region. Previous studies have suggested that the SAM index has a major influence on the formation of WSPs (Gordon et al. 2007; Cheon and Gordon 2019). In E3SMv0-HR, we did not find a clear relationship between surface salinity in the Weddell Sea and the SAM index calculated over the entire Southern Ocean. In some studies, the SAM index is considered to be a proxy for the strength of the Southern Hemisphere westerlies (with an inverse relationship). Although that is often the case in E3SMv0-HR, we could not justify using the SAM index as a clear proxy for factors influencing surface salinity, dry atmospheric conditions, or wind stress curl in the Weddell Sea.

In parallel to our finding that WSPs are preceded by sustained periods of negative wind stress curl anomalies, we also find that years with no simulated open-ocean polynyas in the Weddell Sea are characterized by less negative wind stress curl, which causes a spindown of the Weddell Gyre. The restratifying effect of a weak Weddell Gyre promotes the accumulation of WDW at depth, thereby increasing the heat and salt 
a) 12-month running mean of Wind Stress Curl in E3SMv0-HR over the Weddell Sea

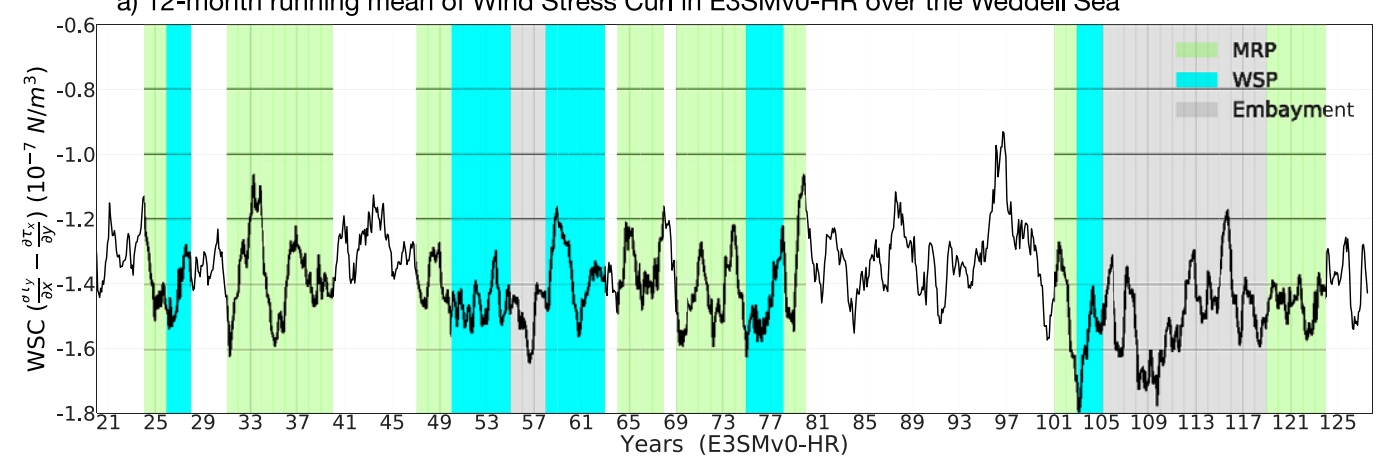

b) 12-month running mean of Wind Stress Curl in ERA5 over the Weddell Sea

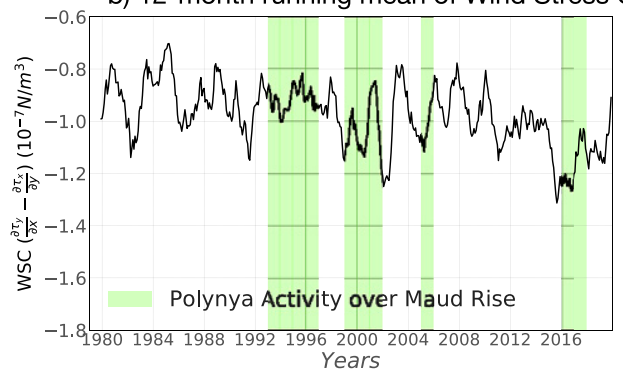

FIG. 19. WSC from (a) the E3SMv0-HR simulation and (b) from ERA-5 (Copernicus Climate Change Service 2017) averaged over the full Weddell Sea. The time series are smoothed using a 12-month centered running mean and are calculated over the area $55^{\circ} \mathrm{W}-40^{\circ} \mathrm{E}, 55^{\circ}-75^{\circ} \mathrm{S}$.

content in the subsurface ocean. The period of recovery of this subsurface heat reservoir is a necessary condition for sustaining winter-long open-ocean polynyas (Dufour et al. 2017; Cheon et al. 2015).

Acknowledgments. Authors P. Kurtakoti, M. Veneziani, and W. Weijer acknowledge support of the U.S. Department of Energy (DOE) Office of Science Biological and Environmental Research (BER) program through the Regional and Global Model Analysis (RGMA) program through the High-Latitude Application and Testing of Earth System Models (HiLATRASM) project. Kurtakoti acknowledges the support of the U.S. Department of Energy through the LANL/LDRD Program and the Center for Non Linear Studies for this work (LA-UR-2022461). Discussions with Tarun Verma have been immensely helpful in developing the ideas for analysis used in sections $3 \mathrm{~b}$ and $3 \mathrm{e}$.

\section{REFERENCES}

Alverson, K., and B. Owens, 1996: Topographic pre-conditioning of openocean deep convection. J. Phys. Oceanogr., 26, 2196-2213, https:// doi.org/10.1175/1520-0485(1996)026<2196:TPOOOD>2.0.CO;2.

Armitage, T. W. K., R. Kwok, A. F. Thompson, and G. Cunningham, 2018: Dynamic topography and sea level anomalies of the Southern Ocean: Variability and teleconnections. J. Geophys. Res. Oceans, 123, 613-630, https:// doi.org/10.1002/2017JC013534.

Armour, K. C., J. Marshall, J. R. Scott, A. Donohoe, and E. R. Newsom, 2016: Southern Ocean warming delayed by circumpolar upwelling and equatorward transport. Nat. Geosci., 9, 549-554, https://doi.org/10.1038/ngeo2731.
Bersch, M., G. A. Becker, H. Frey, and K. P. Koltermann, 1992: Topographic effects of the Maud Rise on the stratification and circulation of the Weddell Gyre. Deep-Sea Res., 39A, 303-331, https://doi.org/10.1016/0198-0149(92)90111-6.

Campbell, E. C., E. A. Wilson, G. W. K. Moore, S. C. Riser, C. E. Brayton, M. R. Mazloff, and L. D. Talley, 2019: Antarctic offshore polynyas linked to Southern Hemisphere climate anomalies. Nature, 570, 319-325, https://doi.org/10.1038/s41586019-1294-0.

Carsey, F. D., 1980: Microwave observation of the Weddell Polynya. Mon. Wea. Rev., 108, 2032-2044, https://doi.org/ 10.1175/1520-0493(1980)108<2032:MOOTWP>2.0.CO;2.

Chapman, B., and J. E. Walsh, 1996: Arctic and Southern Ocean sea ice concentrations version 1. NSIDC National Snow Ice Data Center, accessed 14 August 2020, https://doi.org/10.7265/ N5057CVT.

Cheon, W. G., and A. L. Gordon, 2019: Open-ocean polynyas and deep convection in the Southern Ocean. Sci. Rep., 9, 6935, https://doi.org/10.1038/s41598-019-43466-2.

— , Y.-G. Park, J. R. Toggweiler, and S.-K. Lee, 2014: The relationship of Weddell polynya and open-ocean deep convection to the Southern Hemisphere westerlies. J. Phys. Oceanogr., 44, 694-713, https://doi.org/10.1175/JPO-D-13-0112.1.

— S. Lee, A. L. Gordon, Y. Liu, C. Cho, and J. J. Park, 2015: Replicating the 1970s Weddell Polynya using a coupled oceansea ice model with reanalysis surface flux fields. Geophys. Res. Lett., 42, 5411-5418, https://doi.org/10.1002/2015GL064364.

Comiso, J. C., and A. L. Gordon, 1987: Recurring polynyas over the Cosmonaut Sea and the Maud Rise. J. Geophys. Res. Oceans, 92, 2819-2833, https://doi.org/10.1029/JC092iC03p02819.

Copernicus Climate Change Service, 2017: ERA5: Fifth generation of ECMWF atmospheric reanalyses of the global climate. 
Copernicus Climate Change Service Climate Data Store (CDS), accessed 18 July 2020, https://cds.climate.copernicus. eu/\#!/search?text $=$ ERA5\& type $=$ dataset.

de Lavergne, C., J. B. Palter, E. D. Galbraith, R. Bernardello, and I. Marinov, 2014: Cessation of deep convection in the open Southern Ocean under anthropogenic climate change. Nat. Climate Change, 4, 278-282, https://doi.org/10.1038/nclimate2132.

Dennis, J. M., and Coauthors, 2011: CAM-SE: A scalable spectral element dynamical core for the Community Atmosphere Model. Int. J. High Perform. Comput. Appl., 26, 74-89, https:// doi.org/10.1177/1094342011428142.

de Steur, L., D. M. Holland, R. D. Muench, and M. G. Mcphee, 2007: The warm-water "halo" around Maud Rise: Properties, dynamics and impact. Deep-Sea Res. I, 54, 871-896, https:// doi.org/10.1016/J.DSR.2007.03.009.

Dufour, C. O., A. K. Morrison, S. M. Griffies, I. Frenger, H. Zanowski, and M. Winton, 2017: Preconditioning of the Weddell Sea polynya by the ocean mesoscale and dense water overflows. J. Climate, 30, 7719-7737, https://doi.org/10.1175/ JCLI-D-16-0586.1.

Fahrbach, E., G. Rohardt, M. Schröder, and V. Strass, 1994: Transport and structure of the Weddell Gyre. Ann. Geophys., 12, 840-855, https://doi.org/10.1007/s00585-994-0840-7.

—, M. Hoppema, G. Rohardt, O. Boebel, O. Klatt, and A. Wisotzki, 2011: Warming of deep and abyssal water masses along the Greenwich meridian on decadal time scales: The Weddell Gyre as a heat buffer. Deep-Sea Res. II, 58, 25092523, https://doi.org/10.1016/j.dsr2.2011.06.007.

Foldvik, A., T. Gammelsrød, and T. Tørresen, 1985: Circulation and water masses on the southern Weddell Sea shelf. Oceanology of the Antarctic Continental Shelf, S. S. Jacobs, Ed., Antarctic Research Series, Vol. 43, Amer. Geophys. Union, 5-20, https:// www.agu.org/books/ar/v043/AR043p0005/AR043p0005.shtml.

Francis, D., C. Eayrs, J. Cuesta, and D. Holland, 2019: Polar cyclones at the origin of the reoccurrence of the Maud Rise Polynya in austral winter 2017. J. Geophys. Res. Atmos., 124, 5251-5267, https://doi.org/10.1029/2019JD030618.

Fyfe, J. C., O. Saenko, K. Zickfeld, M. Eby, and A. J. Weaver, 2007: The role of poleward-intensifying winds on Southern Ocean warming. J. Climate, 20, 5391-5400, https://doi.org/10.1175/ 2007JCLI1764.1.

Gong, D., and S. Wang, 1999: Definition of Antarctic Oscillation index. Geophys. Res. Lett., 26, 459-462, https://doi.org/ 10.1029/1999GL900003.

Gordon, A. L., 1982: Weddell Deep Water: Source and variability. J. Mar. Res., 16, 199-217.

_ 2014: Southern Ocean polynya. Nat. Climate Change, 4, 249250, https://doi.org/10.1038/nclimate2179.

_ J. Geophys. Res., 95, 11 655-11 672, https://doi.org/10.1029/ JC095iC07p11655.

— M. Misbeck, and J. C. Comiso, 2007: A possible link between the Weddell Polynya and the southern annular mode. J. Climate, 20, 2558-2571, https://doi.org/10.1175/JCLI4046.1.

Hall, A., and M. Visbeck, 2002: Synchronous variability in the Southern Hemisphere atmosphere, sea ice, and ocean resulting from the annular mode. J. Climate, 15, 3043-3057, https:// doi.org/10.1175/1520-0442(2002)015<3043:SVITSH>2.0.CO;2.

Hallberg, R., 2013: Using a resolution function to regulate parameterizations of oceanic mesoscale eddy effects. Ocean Modell., 72, 92-103, https://doi.org/10.1016/j.ocemod.2013.08.007.

Hirabara, M., H. Tsujino, H. Nakano, and G. Yamanaka, 2012: Formation mechanism of the Weddell Sea Polynya and the impact on the global abyssal ocean. J. Oceanogr., 68, 771-796, https://doi.org/10.1007/s10872-012-0139-3.

Holland, D. M., 2001: Explaining the Weddell Polynya-A large ocean eddy shed at Maud Rise. Science, 292, 1697-1700, https://doi.org/10.1126/science.1059322.

Hoppema, M., 2004: Weddell Sea is a globally significant contributor to deep-sea sequestration of natural carbon dioxide. Deep-Sea Res. I, 51, 1169-1177, https://doi.org/10.1016/J.DSR.2004.02.011.

Hunke, E. C., and W. H. Lipscomb, 2008: CICE: The Los Alamos sea ice model user's manual, version 4. Los Alamos National Laboratory Tech. Rep. LA-CC-06-0, 76 pp.

Hurrell, J. W., and Coauthors, 2013: The Community Earth System Model: A framework for collaborative research. Bull. Amer. Meteor. Soc., 94, 1339-1360, https://doi.org/10.1175/BAMS-D12-00121.1.

Jena, B., M. Ravichandran, and J. Turner, 2019: Recent reoccurrence of large open-ocean polynya on the Maud Rise Seamount. Geophys. Res. Lett., 46, 4320-4329, https://doi.org/ 10.1029/2018GL081482.

Kaufman, Z. S., N. Feldl, W. Weijer, and M. Veneziani, 2020: Causal interactions between Southern Ocean polynyas and high-latitude atmosphere-ocean variability. J. Climate, 33, 4891-4905, https://doi.org/10.1175/JCLI-D-19-0525.1.

Kjellsson, J., and Coauthors, 2015: Model sensitivity of the Weddell and Ross Seas, Antarctica, to vertical mixing and freshwater forcing. Ocean Modell., 94, 141-152, https://doi.org/10.1016/ j.ocemod.2015.08.003.

Kurtakoti, P., M. Veneziani, A. Stössel, and W. Weijer, 2018: Preconditioning and formation of Maud Rise Polynyas in a high-resolution Earth system model. J. Climate, 31, 9659-9678, https://doi.org/10.1175/JCLI-D-18-0392.1.

Kurtz, N. T., and T. Markus, 2012: Satellite observations of Antarctic sea ice thickness and volume. J. Geophys. Res., 117, C08025, https://doi.org/10.1029/2012JC008141.

Large, W. G., J. C. Mcwilliams, and S. C. Doney, 1994: Oceanic vertical mixing-A review and a model with a nonlocal boundary-layer parameterization. Rev. Geophys., 32, 363-403, https://doi.org/10.1029/94RG01872.

Lawrence, D. M., and Coauthors, 2011: Parameterization improvements and functional and structural advances in version 4 of the Community Land Model. J. Adv. Model. Earth Syst., 3, M03001, https://doi.org/10.1029/2011MS00045.

Marinov, I., A. Gnanadesikan, J. R. Toggweiler, and J. L. Sarmiento, 2006: The Southern Ocean biogeochemical divide. Nature, 441, 964-967, https://doi.org/10.1038/nature04883.

Marshall, G. J., 2003: Trends in the southern annular mode from observations and reanalyses. J. Climate, 16, 4134-4143, https:// doi.org/10.1175/1520-0442(2003)016<4134:TITSAM > 2.0.CO;2.

Marshall, J., and F. Schott, 1999: Open-ocean convection: Observations, theory, and models. Rev. Geophys., 37, 1-64, https://doi.org/10.1029/98RG02739.

Martin, T., W. Park, and M. Latif, 2013: Multi-centennial variability controlled by Southern Ocean convection in the Kiel Climate Model. Climate Dyn., 40, 2005-2022, https://doi.org/ 10.1007/s00382-012-1586-7.

Martinson, D. G., P. D. Killworth, and A. L. Gordon, 1981: A convective model for the Weddell Polynya. J. Phys. Oceanogr., 11, 466-488, https://doi.org/10.1175/1520-0485(1981)011<0466: ACMFTW $>2.0 . \mathrm{CO} ; 2$.

Maslanik, J., and J. Stroeve, 1999: Near-Real-Time DMSP SSMIS Daily Polar Gridded Sea Ice Concentrations, version 1. NASA National Snow and Ice Data Center Distributed Active Archive Center, accessed 6 June 2018, https://doi.org/10.5067/U8C09DWVX9LM. 
Mazloff, M. R., P. Heimbach, and C. Wunsch, 2010: An eddypermitting Southern Ocean state estimate. J. Phys. Oceanogr., 40, 880-899, https://doi.org/10.1175/2009JPO4236.1.

Meredith, M. P., A. S. Meijers, A. C. Naveira Garabato, P. J. Brown, H. J. Venables, E. P. Abrahamsen, L. Jullion, and M.-J. Messias, 2015: Circulation, retention, and mixing of waters within the Weddell-Scotia confluence, Southern Ocean: The role of stratified Taylor columns. J. Geophys. Res. Oceans, 120, 547-562, https://doi.org/10.1002/2014JC010462.

Morales Maqueda, M., A. J. Willmott, and N. R. T. Biggs, 2004: Polynya dynamics: A review of observations and modeling. Rev. Geophys., 42, RG1004, https://doi.org/10.1029/ 2002RG000116.

Muench, R. D., J. H. Morison, L. Padman, D. Martinson, P. Schlosser, B. Huber, and R. Hohmann, 2001: Maud Rise revisited. J. Geophys. Res., 106, 2423-2440, https://doi.org/ 10.1029/2000JC000531.

Oke, P. R., and M. H. England, 2004: Oceanic response to changes in the latitude of the Southern Hemisphere subpolar westerly winds. J. Climate, 17, 1040-1054, https://doi.org/10.1175/15200442(2004)017<1040:ORTCIT>2.0.CO;2.

Orsi, A. H., W. D. Nowlin Jr., and T. Whitworth, 1993: On the circulation and stratification of the Weddell Gyre. Deep-Sea Res., 40, 169-203, https://doi.org/10.1016/0967-0637(93)90060-G.

Parkinson, C. L., 1983: On the development and cause of the Weddell Polynya in a sea ice simulation. J. Phys. Oceangr., 13, 501-511, https://doi.org/10.1175/1520-0485(1983)013<0501: OTDACO $>2.0 . \mathrm{CO} ; 2$.

Patara, L., and C. W. Böning, 2014: Abyssal ocean warming around Antarctica strengthens the Atlantic overturning circulation. Geophys. Res. Lett., 41, 3972-3978, https://doi.org/10.1002/ 2014GL059923.

Rignot, E., S. S. Jacobs, J. Mouginot, and B. Scheuchl, 2013: Iceshelf melting around Antarctica. Science, 341, 266-270, https:// doi.org/10.1126/science.1235798.

Russell, J. L., K. W. Dixon, A. Gnanadesikan, R. J. Stouffer, and J. R. Toggweiler, 2006: The Southern Hemisphere westerlies in a warming world: Propping open the door to the deep ocean. J. Climate, 19, 6382-6390, https://doi.org/10.1175/JCLI3984.1.

Ryan, S., M. Schröder, O. Huhn, and R. Timmermann, 2016: On the warm inflow at the eastern boundary of the Weddell Gyre. Deep-Sea Res. I, 107, 70-81, https://doi.org/10.1016/ J.DSR.2015.11.002.

Schröder, M., and E. Fahrbach, 1999: On the structure and the transport of the eastern Weddell Gyre. Deep-Sea Res. II, 46, 501-527, https://doi.org/10.1016/S0967-0645(98)00112-X.

Small, R. J., and Coauthors, 2014: A new synoptic scale resolving global climate simulation using the Community Earth System Model. J. Adv. Model. Earth Syst., 6, 1065-1094, https:// doi.org/10.1002/2014MS000363.

Smith, R., and Coauthors, 2010: The Parallel Ocean Program (POP) reference manual: Ocean component of the Community Climate System Model (CCSM). Los Alamos National Laboratory Rep. LAUR-01853, 140 pp., https://www.cesm.ucar.edu/models/cesm2/ ocean/doc/sci/POPRefManual.pdf.

Sohail, T., B. Gayen, and A. M. Hogg, 2020: The dynamics of mixed layer deepening during open-ocean convection. J. Phys. Oceanogr., 50, 1625-1641, https://doi.org/10.1175/JPO-D-190264.1.
Stössel, A., and S.-J. Kim, 2001: Decadal deep-water variability in the subtropical Atlantic and convection in the Weddell Sea. J. Geophys. Res., 106, 22 425-22 440, https://doi.org/10.1029/ 2000JC000335.

- D. Notz, F. A. Haumann, H. Haak, J. Jungclaus, and U. Mikolajewicz, 2015: Controlling high-latitude Southern Ocean convection in climate models. Ocean Modell., 86, 5875, https://doi.org/10.1016/j.ocemod.2014.11.008.

Su, Z., A. L. Stewart, and A. F. Thompson, 2014: An idealized model of Weddell Gyre export variability. J. Phys. Oceanogr., 44, 1671-1688, https://doi.org/10.1175/JPO-D-13-0263.1.

Swart, N. C., S. T. Gille, J. C. Fyfe, and N. P. Gillett, 2018: Recent Southern Ocean warming and freshening driven by greenhouse gas emissions and ozone depletion. Nat. Geosci., 11, 836-841, https://doi.org/10.1038/s41561-018-0226-1.

Swingedouw, D., T. Fichefet, H. Goosse, and M. F. Loutre, 2009: Impact of transient freshwater releases in the Southern Ocean on the AMOC and climate. Climate Dyn., 33, 365-381, https:// doi.org/10.1007/s00382-008-0496-1.

Thompson, D., J. Wallace, and G. Hegerl, 1999: Annular modes in the extratropical circulation. Part II: Trends. J. Climate, 13, 1018-1036, https://doi.org/10.1175/1520-0442(2000)013<1018: AMITEC $>2.0 . \mathrm{CO} ; 2$.

Timmermann, R., 2002: Simulations of ice-ocean dynamics in the Weddell Sea. 2. Interannual variability 1985-1993. J. Geophys. Res., 107, 3025, https://doi.org/10.1029/2000JC000742.

Weijer, W., M. Veneziani, A. Stössel, M. W. Hecht, N. Jeffery, A. Jonko, T. Hodos, and H. Wang, 2017: Local atmospheric response to an open-ocean polynya in a high-resolution climate model. J. Climate, 30, 1629-1641, https://doi.org/10.1175/ JCLI-D-16-0120.1.

Williams, G., T. Maksym, J. Wilkinson, C. Kunz, C. Murphy, P. Kimball, and H. Singh, 2015: Thick and deformed Antarctic sea ice mapped with autonomous underwater vehicles. Nat. Geosci., 8, 61-67, https://doi.org/10.1038/ngeo2299.

Wilson, E. A., S. C. Riser, E. C. Campbell, and A. P. S. Wong, 2019: Winter upper-ocean stability and ice-ocean feedbacks in the sea ice-covered Southern Ocean. J. Phys. Oceanogr., 49, 1099-1117, https://doi.org/10.1175/JPO-D-18-0184.1.

Worby, A. P., C. A. Geiger, M. J. Paget, M. L. Van Woert, S. F. Ackley, and T. L. DeLiberty, 2008: Thickness distribution of Antarctic sea ice. J. Geophys. Res., 113, C05S92, https:// doi.org/10.1029/2007JC004254.

Zanowski, H., and R. Hallberg, 2017: Weddell polynya transport mechanisms in the abyssal ocean. J. Phys. Oceanogr., 47, 29072925, https://doi.org/10.1175/JPO-D-17-0091.1.

$\longrightarrow, \ldots$, and J. L. Sarmiento, 2015: Abyssal ocean warming and salinification after Weddell Polynyas in the GFDL CM2G coupled climate model. J. Phys. Oceanogr., 45, 2755-2772, https://doi.org/10.1175/JPO-D-15-0109.1.

Zhang, Z., T. Vihma, A. Stössel, and P. Uotila, 2015: The role of wind forcing from operational analyses for the model representation of Antarctic coastal sea ice. Ocean Modell., 94, 95111, https://doi.org/10.1016/j.ocemod.2015.07.019.

Zwally, H. J., J. C. Comiso, C. L. Parkinson, W. J. Campbell, F. D. Carsey, and P. Gloersen, 1983: Antarctic sea ice, 1973-1976: Satellite passive-microwave observations. National Aeronautics and Space Administration Doc. NASA SP-459, 206 pp., https:// ntrs.nasa.gov/citations/19840002650. 